\title{
Preparation via a NHC Dimer Complex, Photophysical Properties, and Device Performance of Heteroleptic Bis(Tridentate) Iridium(III) Emitters
}

\author{
Vadim Adamovich, ${ }^{\mathrm{b}}$ Pierre-Luc T. Boudreault, ${ }^{\mathrm{b}}$ Miguel A. Esteruelas, ${ }^{* a}$ Daniel Gómez-Bautista, ${ }^{\mathrm{a}}$ Ana M. López, ${ }^{\mathrm{a}}$ \\ Enrique Oñate, ${ }^{a}$ Jui-Yi Tsai ${ }^{b}$ \\ aDepartamento de Química Inorgánica - Instituto de Síntesis Química y Catálisis Homogénea (ISQCH) - Centro de Innovación en \\ Química Avanzada (ORFEO-CINQA), Universidad de Zaragoza - CSIC, 50009 Zaragoza, Spain \\ ${ }^{b}$ Universal Display Corporation, 375 Phillips Boulevard, Ewing, New Jersey 08618, USA
}

\begin{abstract}
The preparation, photophysical properties, and applicability to the fabrication of organic light-emitting diodes (OLEDs) of new phosphorescent bis(tridentate) $\left[5 t+4 t^{\prime}\right]$ iridium(III) molecules are described. Treatment of $\left[\operatorname{Ir}(\mu-\mathrm{OMe})\left(\eta^{4}-\mathrm{COD}\right)\right]_{2}(1 ; \mathrm{COD}=1,5-$ cyclooctadiene) with 5-tert-butyl-1,3-bis(3-isopropylimidazolium) benzene diiodide $\left(\left[{ }^{\mathrm{i}} \mathrm{PrHImC}{ }_{6} \mathrm{H}_{3}\left(5-{ }^{-} \mathrm{Bu}\right) \mathrm{HIm}{ }^{\mathrm{i}} \mathrm{Pr}\right][\mathrm{I}]_{2}\right)$, in the presence of $\mathrm{KI}$, leads to $\left[\operatorname{IrI}(\mu-\mathrm{I})\left\{\kappa^{3}-C, C, C \text { - }\left[{ }^{\mathrm{i}} \mathrm{PrImC}_{6} \mathrm{H}_{2}\left(5-{ }^{\mathrm{t}} \mathrm{Bu}\right) \mathrm{Im}^{\mathrm{i}} \mathrm{Pr}\right]\right\}\right]_{2}$ (2). This complex reacts with 2-(1H-imidazol-2-yl)-6-phenylpyridine (HNImpyC $\left.{ }_{6} \mathrm{H}_{5}\right)$ and 2-( $1 H$-benzimidazol-2-yl)-6-phenylpyridine $\left(\mathrm{HNBzimpyC}_{6} \mathrm{H}_{5}\right)$, in the presence of $\mathrm{Na}_{2} \mathrm{CO}_{3}$, to afford the bis (tridentate) derivatives $\operatorname{Ir}\left\{\kappa^{3}-C, C, C\right.$ - $\left.\left[{ }^{\mathrm{P}} \mathrm{PrImC}_{6} \mathrm{H}_{2}\left(5-{ }^{\mathrm{B}} \mathrm{Bu}\right) \operatorname{Im}{ }^{\mathrm{i}} \operatorname{Pr}\right]\right\}\left\{\kappa^{3}-N, N, C\right.$ - $\left.\left[\mathrm{NImpyC}_{6} \mathrm{H}_{4}\right]\right\} \quad(4) \quad$ and $\quad \operatorname{Ir}\left\{\kappa^{3}-C, C, C\right.$ - $\left.\left[{ }^{\mathrm{i}} \mathrm{PrImC}_{6} \mathrm{H}_{2}\left(5-{ }^{\mathrm{t}} \mathrm{Bu}\right) \operatorname{Im} \mathrm{Pr}\right]\right\}\left\{\kappa^{3}-N, N, C\right.$ $\left.\left[\mathrm{NBzimpyC}_{6} \mathrm{H}_{4}\right]\right\}$ (5). Complexes 4 and 5 are phosphorescent emitters $\left(\lambda_{\mathrm{em}}=482-590 \mathrm{~nm}\right)$, which display observed lifetimes in the range 1.2-11.7 $\mu \mathrm{s}$. They show high quantum yields in both doped poly(methyl)methacrylate) films and in 2-methyltetrahydrofuran at room temperature $(\phi=0.73-0.49)$. Complex 5 has demonstrated to be suitable to be used as a reasonably efficient phosphorescent greenish-yellow emitter for OLED devices with electroluminescence $\lambda_{\max }$ of $552 \mathrm{~nm}$ and maximum external quantum efficiency (EQE) of $12 \%$.
\end{abstract}

\section{INTRODUCTION}

Phosphorescent iridium(III) molecules are currently positioned at the forefront of the photochemistry by their applications in the completion of phosphorescent organic light-emitting diodes (PHOLEDs). ${ }^{1}$ Furthermore, their emissive properties can be governed combining different classes of ligands at the coordination sphere of the metal center. ${ }^{2}$ The focus is mainly centered on compounds bearing three bidentate 3 -electron donor ligands $(3 b)$ of two or three different types; i.e., molecules $\left[3 b+3 b+3 b^{3}\right]^{3}$ or $[3 b$ $\left.+3 b^{\prime}+3 b^{\prime \prime}\right] .^{4}$ However, they undergo two main issues: the existence of structural isomers with their own photophysical properties and a high tendency to afford mixtures of compounds resulting from ligand redistribution equilibria. ${ }^{4 b} \mathrm{~A}$ possible solution is to reduce the number of ligands at the metal coordination sphere increasing their denticity. In this context, the use of pincer ligands to form bis(tridentate) $\left[5 t+4 t^{\prime}\right]$ complexes is of great interest. ${ }^{5}$ Although, the application of these ligands could produce a reduction of the emission efficiency, as a consequence of structural distortions due to the rigidity of the pincer, ${ }^{6}$ the increase of the strength of the interaction metal-ligand should disfavor the thermal induced quenching. ${ }^{7}$

The development of methods for the synthesis of iridium(III) molecular complexes with two tridentate ligands have received scarce attention, despite that the advancement of a scientific area based on chemical compounds is directly related to their accessibil- ity. In 2004, Williams and co-workers discovered that 1,3-di(2pyridyl)-4,6-dimethylbenzene (dpyxH) reacts with $\mathrm{IrCl}_{3} \cdot 3 \mathrm{H}_{2} \mathrm{O}$ in 2-ethoxyethanol to give the iridium(III) dimer $[\operatorname{IrCl}(\mu$ $\mathrm{Cl})($ dpyx $)]_{2},{ }^{8}$ which subsequently allowed the coordination of a $4 \mathrm{t}-$ ligand to generate phosphorescent bis(tridentate) iridium(III) complexes (Scheme 1).9 In 2015, Chi, Chang, Chou, and coworkers employed the same procedure to prepare emitters derived from related $5 \mathrm{t}-\mathrm{N}, \mathrm{C}, \mathrm{N}$-pincer ligands. ${ }^{10}$

Scheme 1. Preparation of $\left[5 t+4 t^{\prime}\right]$ Bis(tridentate) Iridium(III) Complex via $[\operatorname{IrCl}(\mu-\mathrm{Cl})(\mathrm{dpyx})]_{2}{ }^{8,9 a}$

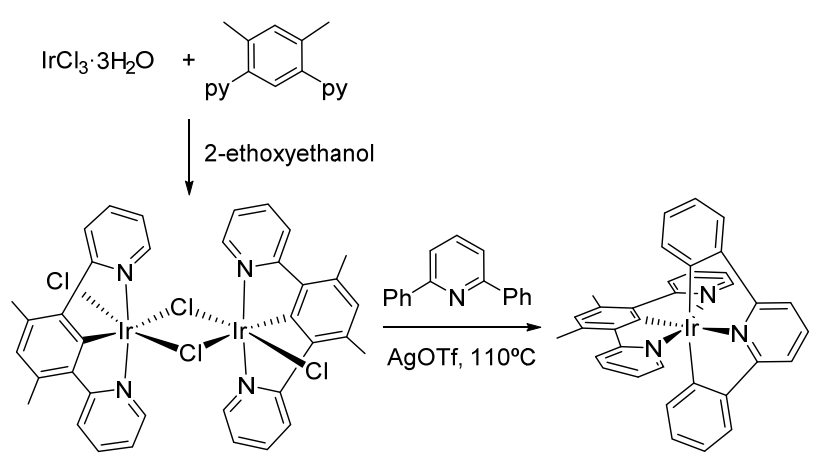

Pyridines are replaced by $\mathrm{N}$-heterocyclic carbenes (NHCs) in order to reach emissions of higher energy. ${ }^{11}$ A noticeable M-NHC $\pi$-back-bonding is present in complexes of third-row electron-rich 
metals. ${ }^{12}$ The $\pi$-acceptor ability of the NHC group effectively lowers the highest occupied molecular orbital (HOMO). In addition, the stronger $\sigma$-donor capacity of the NHC ligand raises the energy of the lowest unoccupied molecular orbital (LUMO). As a result of all this, a wider band gap is generated. Furthermore, the strengthening of the bond prevents the formation of ${ }^{3} \mathrm{MC}$ states, whereas decreases the kinetic lability of the dissociative processes avoiding degradation pathways. ${ }^{13}$ Unfortunately, the coordination of a NHC group to iridium is an issue much more complex than the coordination of a pyridine. ${ }^{14}$ As a consequence, the procedures to prepare NHC-analogous to the dimer shown in Scheme 1 are scarce and little developed. In 2008, Braunstein and co-workers reported that the treatment of the well-known compound $\left[\operatorname{Ir}(\mu-\mathrm{Cl})\left(\eta^{4}-\mathrm{COD}\right)\right]_{2}$ ( $\mathrm{COD}=1,5$-cyclooctadiene $)$ with the corresponding imidazolium iodide salts, $\mathrm{Et}_{3} \mathrm{~N}$, and $\mathrm{KI}$ in acetonitrile leads to the dimers $[\operatorname{IrI}(\mu-$ I) $\left.\left\{\kappa^{3}-C, C, C-\left[\mathrm{RImC}_{6} \mathrm{H}_{3} \mathrm{ImR}\right]\right\}\right]_{2}\left(\mathrm{R}={ }^{\mathrm{t}} \mathrm{Bu},{ }^{\mathrm{i}} \mathrm{Pr}\right)$ in $30 \%$ yied. ${ }^{15} \mathrm{In}$ parallel, Hollis' group increased the yield of the 'Bu-dimer up to $68 \%$, using the same starting compounds and $\mathrm{Zr}(\mathrm{Me})_{4}$ as a transmetalation agent. ${ }^{16}$ In recent years, Chi, Chou, and co-workers have discovered interesting [ $\left.5 t+4 t^{\prime}\right]$ emitters containing 1,3bis(imidazolylidene)phenyl groups as the $5 \mathrm{t}$ ligand, whereas the $4 \mathrm{t}^{\prime}$ component of the structure bears at least one functionalized pyrazolate group. ${ }^{17}$ Their synthesis involves one-pot procedures, which also afford low yields. Ligands 4 t bearing a 2-pyridyl-pyrazolate moiety, and to a lesser extent triazolate and tetraazolate instead pyrazolate, are attracting great interest because of the $\sigma$-donor properties of the azolates, which combined with the $\pi$-acceptor ability of the pyridyl group, appear to give rise to a noticeable electron delocalization over the resulting five-membered heterometalacycle. ${ }^{1 \mathrm{f}, 18}$

We have recently reported a $[6 \mathrm{tt}+3 \mathrm{~b}]$ family of iridium(III) blue-green emitters, where the $6 \mathrm{tt}$ ligand is a dianionic $C, C, C, C$ tetradentate group containing two aryl-NHC units. Their synthesis took place through the dimer $\left[\operatorname{Ir}(\mu-\mathrm{I})\left\{\kappa^{4}-C, C, C, C\right.\right.$ $\left.\left.\left[\mathrm{C}_{6} \mathrm{H}_{4} \operatorname{Im}\left(\mathrm{CH}_{2}\right)_{4} \operatorname{ImC} \mathrm{C}_{6} \mathrm{H}_{4}\right]\right\}\right]_{2}$, which was obtained from $[\operatorname{Ir}(\mu$ $\left.\mathrm{OMe})\left(\eta^{4}-\mathrm{COD}\right)\right]_{2}$ and 1,1'-diphenyl-3,3'-butylenediimidazolium diiodide (Scheme 2).${ }^{19}$ The success in the preparation of this family of compounds, encouraged us to apply the same concept to the preparation of $\left[5 t+4 t^{\prime}\right]$ iridium(III) emitters, bearing monoanionic 5t and dianionic 4t' ligands based on a 1,3bis(imidazolylidene)phenyl group and a pincer with a 2-pyridylimidazolate or -benzimidazolate moiety, respectively. This paper describes the synthesis of a $[\operatorname{IrI}(\mu-\mathrm{I})(5 \mathrm{t})]_{2}$ dimer, which is an efficient entry to the target emitters. Their photophysical properties, including the fabrication of an OLED device of one of them, are also reported.

\section{RESULTS AND DISCUSSION}

Synthesis of the $[\operatorname{IrI}(\mu \text {-I })(5 t)]_{2}$ Dimer Containing a Tridentate Aryl-bis(NHC) Ligand. The methoxide ligand of compounds $\left[\mathrm{M}(\mu-\mathrm{OMe})\left(\eta^{4}-\mathrm{COD}\right)\right]_{2}(\mathrm{M}=\mathrm{Rh}, \mathrm{Ir})$ has proven to promote the direct metalation of imidazolium salts. ${ }^{20}$ In agreement with this, in the absence of any Brønsted base, the treatment of the iridium derivative $\left[\operatorname{Ir}(\mu \text {-OMe })\left(\eta^{4} \text {-COD }\right)\right]_{2}(1)$ with 2 mol of 5-tert-butyl1,3-bis(3-isopropylimidazolium)benzene diiodide $\left(\left[{ }^{\mathrm{i}} \mathrm{PrHImC}{ }_{6} \mathrm{H}_{3}\left(5-{ }^{\mathrm{t}} \mathrm{Bu}\right) \mathrm{HIm}^{\mathrm{i}} \mathrm{Pr}\right][\mathrm{I}]_{2}\right)$ and $10 \mathrm{~mol}$ of $\mathrm{KI}$, in 2- ethoxyethanol, at $120^{\circ} \mathrm{C}$, for $18 \mathrm{~h}$ leads to the dimer $\left[\operatorname{IrI}(\mu-\mathrm{I})\left\{\kappa^{3}-C, C, C\right.\right.$ $\left.\left.\left[{ }^{\mathrm{P}} \mathrm{PrImC}{ }_{6} \mathrm{H}_{2}\left(5-{ }^{\mathrm{t}} \mathrm{Bu}\right) \mathrm{Im}^{\mathrm{i}} \mathrm{Pr}\right]\right\}\right]_{2}$ (2) containing the bis(NHC) $C, C, C$ pincer ligand, which was isolated in $47 \%$ yield as a brown solid
(Scheme 3).

Scheme 2. Preparation of $[6 \mathrm{tt}+3 \mathrm{~b}]$ Iridium(III) Complexes via $\left[\operatorname{Ir}(\boldsymbol{\mu}-\mathrm{I})\left\{\boldsymbol{\kappa}^{4}-\boldsymbol{C}, \boldsymbol{C}, \boldsymbol{C}, \boldsymbol{C}-\left[\mathrm{C}_{6} \mathrm{H}_{4} \operatorname{Im}\left(\mathrm{CH}_{2}\right)_{4} \operatorname{ImC} \mathrm{C}_{6} \mathrm{H}_{4}\right]\right\}\right]_{2}{ }^{19}$

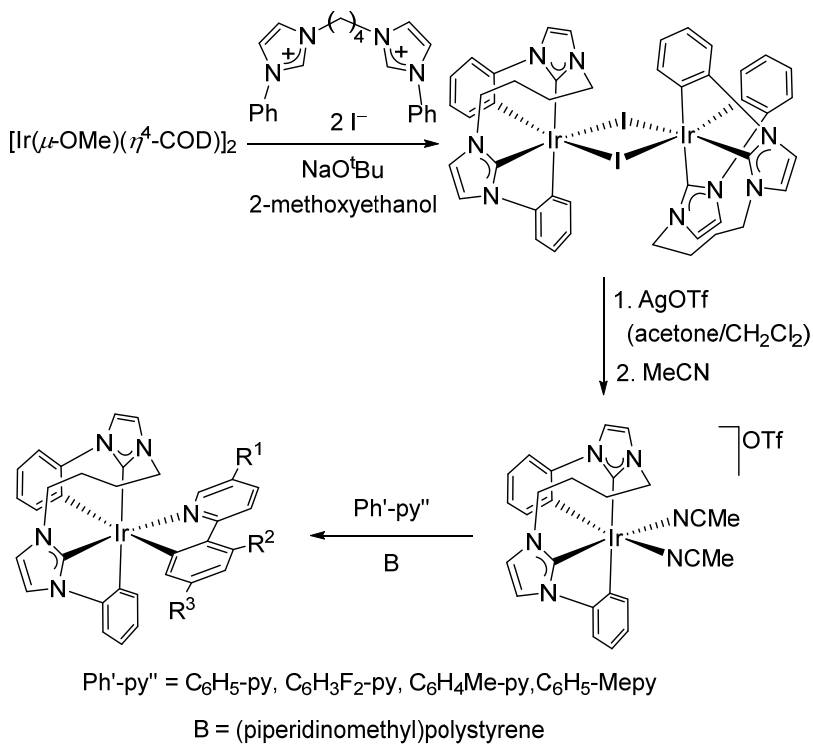

Scheme 3. Preparation of Dimer 2

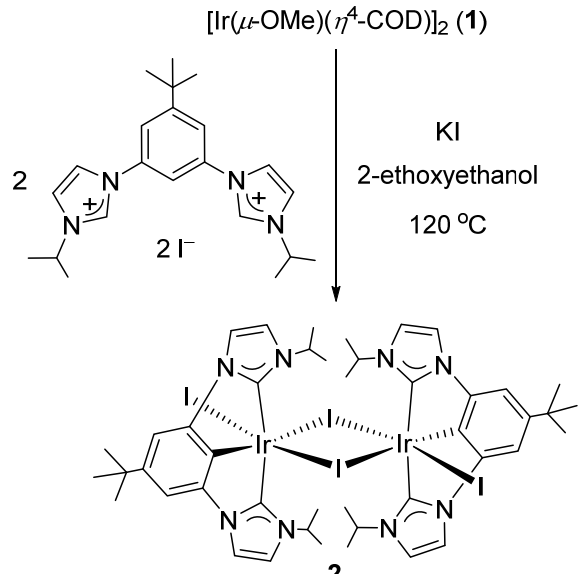

$\mathrm{CH}_{3} \mathrm{CN}, 80^{\circ} \mathrm{C}$

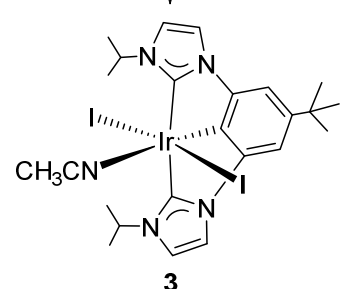

Complex 2 is insoluble in acetone, ethers, alcohols, hydrocarbons, and chlorinated solvents. In acetonitrile, under reflux, the iodide bridges are broken and the resulting mononuclear fragments saturate the metal center by coordination of a solvent molecule to afford $\operatorname{IrI}_{2}\left\{\kappa^{3}-C, C, C\right.$-[ $\left.\left.{ }^{\mathrm{i}} \operatorname{PrImC}_{6} \mathrm{H}_{2}\left(5-{ }^{\mathrm{t}} \mathrm{Bu}\right) \mathrm{Im}^{\mathrm{i}} \mathrm{Pr}\right]\right\}\left(\mathrm{CH}_{3} \mathrm{CN}\right)$ This complex was isolated as a pale-green solid in $87 \%$ yield and characterized by X-ray diffraction analysis. The structure has three chemically equivalent, but crystallographically independent, mole- 
cules in the asymmetric unit. Figure 1 shows one of them. The $5 \mathrm{t}$ $C, C, C$-ligand coordinates in the expected mer-fashion with imidazolylidene-iridium-imidazolylidene angles of 155.4(8) ${ }^{\circ}$, 154.6(7) ${ }^{\circ}$, and $155.2(7)^{\circ}$ (C1-Ir1-C17), the iodide ligands disposed mutually trans (I1-Ir1-I2 $=174.17(5)^{\circ}, 174.25(5)^{\circ}$, and $\left.176.38(5)^{\circ}\right)$ and the acetonitrile molecule located trans to the central aryl group $\left(\mathrm{N} 5-\mathrm{Ir} 1-\mathrm{C} 8=176.1(8)^{\circ}\right.$, $175.7(8)^{\circ}$, and $\left.178.8(8)^{\circ}\right)$. The iridium-imidazolylidene distances of $2.09(2)$,

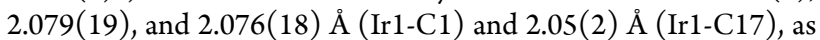
well as the iridium-aryl bond lengths of 1.977(18), 1.95(2), and 1.97(2) $\AA$ (Ir1-C8) compare well with those reported for iridium complexes containing related pincer ligands. ${ }^{14 b, c, e-h, 15,16,17}$ The metalated carbon atoms give rise to singlets at 163.7 ( $\mathrm{C} 1$ and $\mathrm{C} 17)$ and 130.4 (C8) ppm in the ${ }^{13} \mathrm{C}\left\{{ }^{1} \mathrm{H}\right\}$ NMR spectrum, in dichloromethane- $d_{2}$, at room temperature.

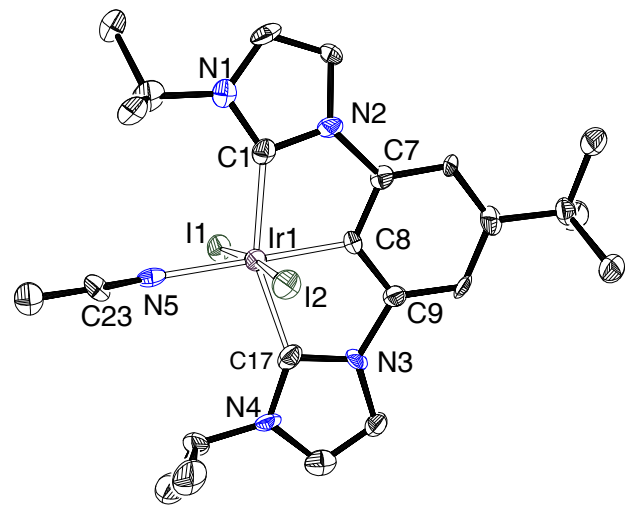

Figure 1. Molecular diagram of complex 3 (50\% probability ellipsoids). Hydrogen atoms are omitted for clarity. Selected bond lengths $(\AA)$ and angles (deg) for the three independent molecules in the asymmetric unit: Ir1-C1 $=2.09(2), 2.079(19), 2.076(18)$, Ir1-C $8=1.977(18)$, 1.95(2), 1.97(2), Ir1-C17 = 2.05(2), 2.05(2), 2.05(2), Ir1-I1 = $2.6640(15), \quad 2.6761(15), \quad 2.6848(14), \quad$ Ir1-I2 $=2.6886(15)$, 2.6697(15), 2.6785(15), Ir1-N5 = 2.107(17), 2.116(16), 2.121(17); C1-Ir1-C17 = 155.4(8), 154.6(7), 155.2(7), I1-Ir1-I2 = 174.17(5), 174.25(5), 176.38(5), N5-Ir1-C8 = 176.1(8), 175.7(8), 178.8(8).

Preparation of the $\left[5 t+4 t^{\prime}\right]$ Emitters. Dimer 2 is certainly useful to prepare this class of emitters. The entry of the dianionic $4 \mathrm{t}^{\prime}$ $N, N, C$-pincer, containing the moieties 2-pyridyl-imidazolate or 2pyridyl-benzimidazolate, was performed using $\mathrm{Na}_{2} \mathrm{CO}_{3}$ as external base to promote the $\mathrm{NH}$-deprotonation of the heterocycles and the heterolytic ortho- $\mathrm{CH}$ bond activation of a phenyl group, the second substituent of the central pyridyl ring. Thus, the treatment of 2 with $2 \mathrm{~mol}$ of 2-(1H-imidazol-2-yl)-6-phenylpyridine (HNImpyC $\left._{6} \mathrm{H}_{5}\right)$, or $2 \mathrm{~mol}$ of 2-(1H-benzimidazol-2-yl)-6-phenylpyridine $\left(\mathrm{HNBzimpyC} \mathrm{H}_{6}\right)$, and $5 \mathrm{~mol}$ of the base in 2-ethoxyethanol, at $120{ }^{\circ} \mathrm{C}$, for $24 \mathrm{~h}$ affords $\operatorname{Ir}\left\{\kappa^{3}-C, C, C\right.$-[ ${ }^{\mathrm{i}} \mathrm{PrImC}_{6} \mathrm{H}_{2}(5-$ $\left.\left.\left.{ }^{\mathrm{t}} \mathrm{Bu}\right) \operatorname{Im} \mathrm{Pr}\right]\right\}\left\{\kappa^{3}-N, N, C\right.$-[NImpyC $\left.\left.\mathrm{N}_{6} \mathrm{H}_{4}\right]\right\} \quad(4), \quad$ or $\operatorname{Ir}\left\{\kappa^{3}-C, C, C\right.$ $\left.\left[{ }^{\mathrm{P}} \mathrm{PrImC}{ }_{6} \mathrm{H}_{2}\left(5-{ }^{\mathrm{t}} \mathrm{Bu}\right) \mathrm{Im}^{\mathrm{i}} \mathrm{Pr}\right]\right\}\left\{\kappa^{3}-N, N, C\right.$ - $\left.\left[\mathrm{NBzimpyC}_{6} \mathrm{H}_{4}\right]\right\}$ respectively. These compounds were isolated as orange solids in $69 \%$ (4) and 54\% (5) yield (Scheme 4).

The formation of $\mathbf{4}$ and $\mathbf{5}$ was confirmed by means of the X-ray diffraction analysis of a single crystal of the former. Figure 2 shows a view of the structure. The coordination of both pincer ligands generates a distorted octahedron with imidazolylidene-iridiumimidazolylidene, imidazolate-iridium-aryl, and pyridine-iridiumaryl(NHC) angles of 154.8(2) (C15-Ir-C31), 156.6(2) (C1-Ir$\mathrm{N} 2$ ), and $177.2(3)^{\circ}$ (N1-Ir-C21), respectively. The iridium-aryl distances of 1.985(6) $\AA$ (Ir-C21) and 2.021(7) $\AA$ (Ir-C1) are slightly shorter than the iridium-imidazolylidene bond lengths of 2.042(7) $\AA$ (Ir-C15) and 2.050(6) $\AA$ (Ir-C31) and all of them compare well with those of 3 , whereas the iridium-imidazolate and iridium-pyridine distances of $2.125(6) \AA$ (Ir-N2) and 2.068(5) $\AA$ (Ir-N1) are similar to those reported for bis(tridentate) iridium(III) complexes containing the 2-pyridyl-pyrazolate unit. ${ }^{17,18}$ In the ${ }^{13} \mathrm{C}\left\{{ }^{1} \mathrm{H}\right\}$ NMR spectra of 4 and 5 , in dichloromethane, at room temperature, the resonances corresponding to the metalated carbon atoms appear at about 164 (imidazolylidene) and between 143 and $144(\mathrm{Ph})$.

\section{Scheme 4. Preparation of the $\left[5 t+4 t^{\prime}\right]$ Emitters 4 and 5}
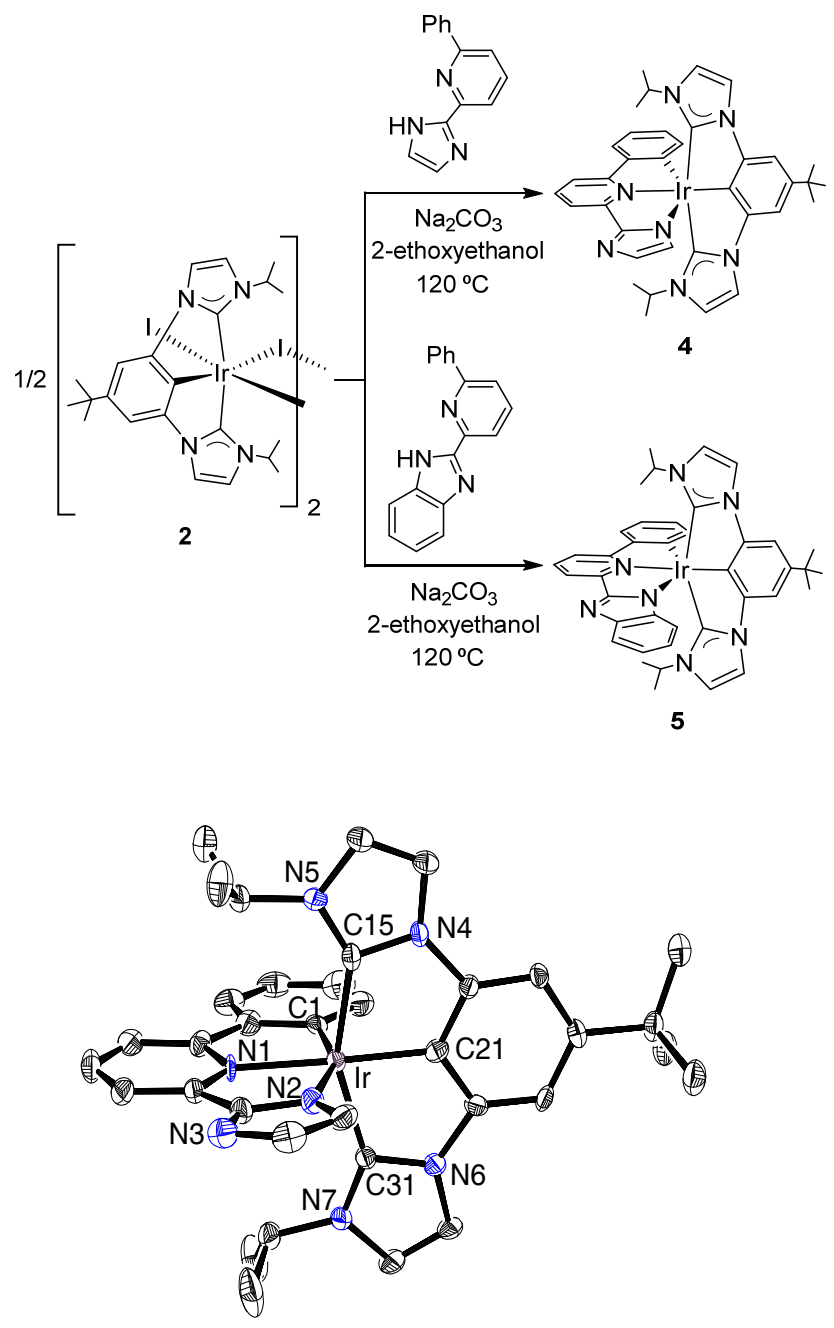

Figure 2. Molecular diagram of complex 4 (50\% probability ellipsoids). Hydrogen atoms are omitted for clarity. Selected bond lengths $(\AA)$ and angles (deg): $\mathrm{Ir}-\mathrm{N} 1=2.068(5), \mathrm{Ir}-\mathrm{N} 2=2.125(6), \mathrm{Ir}-\mathrm{C} 1=2.021(7)$, $\mathrm{Ir}-\mathrm{C} 21=1.985(6), \mathrm{Ir}-\mathrm{C} 15=2.042(7), \mathrm{Ir}-\mathrm{C} 31=2.050(6), \mathrm{N} 1-\mathrm{Ir}-$ $\mathrm{C} 21=177.2(3), \mathrm{C} 1-\mathrm{Ir}-\mathrm{N} 2=156.6(2), \mathrm{C} 15-\mathrm{Ir}-\mathrm{C} 31=154.8(2)$.

Photophysical and Electrochemical Properties of 4 and 5. UV/vis absorption data of $2.0 \times 10^{-5}$ 2-methyltetrahydrofuran (MeTHF) solutions of 4 and 5 , at room temperature, are collected in Table 1 and Figures S11-S12. Like for other iridium $\left[5 t+4 t^{3}\right]$-complexes, ${ }^{8}$ $10,17,18$ the spectra of both compounds show three different zones: $<300,300-430$, and $>440 \mathrm{~nm}$. Time dependent DFT calculations (B3LYP-GD3//SDD(f)/6-31G**), performed in tetrahydrofuran 
Table 1. Selected Experimental UV-Vis Absorptions for 4 and 5 (in MeTHF) and Computed TD-DFT (in THF) Vertical Excitation Energies and their Major Contributions

\begin{tabular}{|c|c|c|c|c|c|c|}
\hline complex & $\begin{array}{l}\lambda_{\exp } \\
(\mathrm{nm})\end{array}$ & $\begin{array}{l}\varepsilon \times 10^{-3} \\
\left(\mathrm{M}^{-1} \cdot \mathrm{cm}^{-1}\right)\end{array}$ & $\begin{array}{l}\text { excitation } \\
\text { energy }(\mathrm{nm})\end{array}$ & $\begin{array}{l}\text { oscillator } \\
\text { strength, } f\end{array}$ & transition & character \\
\hline \multirow[t]{7}{*}{4} & 274 & 34.8 & 269 & 0.1771 & HOMO-6 $\rightarrow$ LUMO (61\%) & LLCT \\
\hline & 306 & 40.5 & 305 & 0.2413 & HOMO-3 $\rightarrow$ LUMO+1 (46\%) & MLCT/LLCT \\
\hline & & & & & HOMO-2 $\rightarrow$ LUMO $+1(25 \%)$ & \\
\hline & 326 & 35.1 & 325 & 0.1191 & HOMO-3 $\rightarrow$ LUMO (84\%) & MLCT/LLCT \\
\hline & 400 & 7.7 & $401\left(S_{1}\right)$ & 0.056 & $\mathrm{HOMO} \rightarrow$ LUMO $(90 \%)$ & MLCT/LLCT \\
\hline & 450 & 1.6 & $461\left(\mathrm{~T}_{1}\right)$ & 0 & $\mathrm{HOMO} \rightarrow$ LUMO (33\%) & ${ }^{3} \mathrm{MLCT} /{ }^{3} \mathrm{LC}$ \\
\hline & & & & & $\mathrm{HOMO} \rightarrow \mathrm{LUMO}+1(35 \%)$ & \\
\hline \multirow[t]{6}{*}{5} & 298 & 19.1 & 290 & 0.0832 & HOMO-5 $\rightarrow$ LUMO+1 (82\%) & LLCT \\
\hline & 330 & 24.5 & 329 & 0.2958 & HOMO-3 $\rightarrow$ LUMO (74\%) & MLCT/LLCT \\
\hline & 360 & 15.8 & 355 & 0.2363 & HOMO-2 $\rightarrow$ LUMO (90\%) & MLCT/LLCT \\
\hline & 422 & 3.2 & $419\left(S_{1}\right)$ & 0.0114 & $\mathrm{HOMO} \rightarrow$ LUMO $(89 \%)$ & MLCT/LLCT \\
\hline & 450 & 1.5 & $470\left(\mathrm{~T}_{1}\right)$ & 0 & $\mathrm{HOMO} \rightarrow$ LUMO (68\%) & ${ }^{3} \mathrm{MLCT} /{ }^{3} \mathrm{LC}$ \\
\hline & & & & & $\mathrm{HOMO} \rightarrow \mathrm{LUMO}+1(15 \%)$ & \\
\hline
\end{tabular}

as solvent, suggest that the absorptions of the highest energy region correspond to ${ }^{1} \pi-\pi^{*}$ intra- e interligand transitions (LLCT), whereas the bands between 300 and $430 \mathrm{~nm}$ correspond to allowed spin metal-to- $N, N, C$-ligand charge transfer $\left({ }^{1} \mathrm{MLCT}\right)$ mixed with $C, C, C$ - to $N, N, C$ - transitions. The very weak absorptions tails after $440 \mathrm{~nm}$ are assigned to formally spin-forbidden ${ }^{3} \mathrm{MLCT}$ transitions, caused by the large spin-orbit coupling introduced by the third row metal center, with some contribution from the ${ }^{3} \pi-\pi^{*}$ transitions.

Plots for the HOMO, LUMO, and LUMO+1 of 4 and 5 are depicted on Figure 3. Further plots for the molecular orbitals involved in the optical transitions and their composition are shown in Figures S13-S14 and Tables S5-S6. As can be seen in Figure 3, for both complexes, the HOMO is located on the iridium atom $(23 \%$ (4) and $31 \%(5))$ and the $C, C, C(13 \%(4)$ and $17 \%(5))$ and $N, N, C$ (64\% (4) and 51\% (5)) ligands, while the LUMO and LUMO+1 are mainly centered on the N,N,C ligand (95 and 97\% (4) and 94 and $98 \%(5)$ ). The calculated $S_{0} \rightarrow S_{1}$ wavelengths of $401 \mathrm{~nm}$ for 4 and $419 \mathrm{~nm}$ for 5 match with the observed onsets of the absorption bands depicted in Figures $\mathrm{S} 11-\mathrm{S} 12$, and are assigned to HOMO $\rightarrow$ LUMO $(90 \%$ (4) and $89 \%$ (5)) transitions. Thus, the excited states can be described as being of mixed $\mathrm{d}(\mathrm{Ir}) / \pi(C, C, C$-ligand $) / \pi(N, N, C$-ligand $) \rightarrow \pi^{*}(N, N, C$-ligand $)$ character; i.e., MLCT/LC/LLCT.

The electrochemical behavior of complexes 4 and 5 was studied using cyclic voltammetry in degassed acetonitrile solutions and referenced versus $\mathrm{Fc} / \mathrm{Fc}^{+}$. The results are summarized in Table 2 . Both complexes showed a reversible oxidation process at $0.23 \mathrm{~V}$, which could be assigned to metal centered $\operatorname{Ir}(\mathrm{III}) / \mathrm{Ir}(\mathrm{IV})$ redox couple, and irreversible reduction waves at $-2.70(4)$ and $-2.60 \mathrm{~V}$ (5). ${ }^{21}$ The observed electrochemical gaps are in agreement with the calculated HOMO-LUMO ones (Table 2) and with those previously reported for other green emissive (vide infra) neutral iridium(III) complexes. ${ }^{17 b, 18 b, 19}$

Complexes $\mathbf{4}$ and $\mathbf{5}$ are green and yellowish green phosphorescent emitters upon photoexcitation, in a doped poly(methyl methacrylate) (PMMA) film at $5 \mathrm{wt} \%$ at room temperature and in MeTHF at room temperature and at $77 \mathrm{~K}$. Figure 4 shows the emission spectra, whereas Table 3 collects calculated and experimental wavelengths, observed lifetimes, quantum yields, and radiative and nonradiative rate constants. The spectra of 4 display vibronic fine structures in agreement with a significant contribution of ligand-centered ${ }^{3} \pi-\pi^{*}$ transitions to the excited state..$^{10,11 e, 17 a, b, 18 b, 22}$

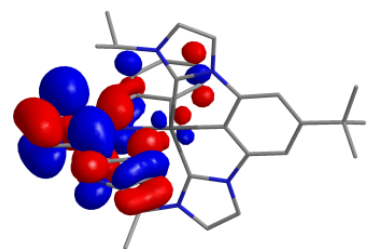

LUMO+1 $(-0.84 \mathrm{eV})$ Ir (2), CCC (1), NNC (97)

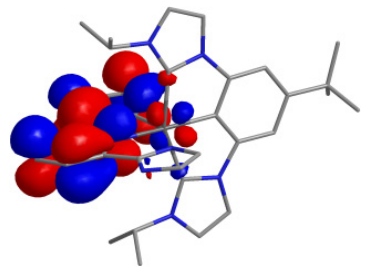

LUMO (-1.09 eV) Ir (3), CCC (2), NNC (95)

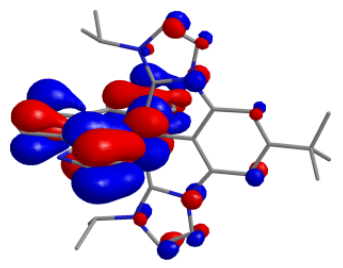

HOMO $(-4.93 \mathrm{eV})$

Ir (23), CCC (13), NNC (64)

4

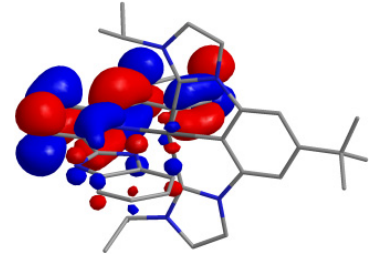

LUMO+1 (-1.15 eV) Ir (1), CCC (0), NNC (98)

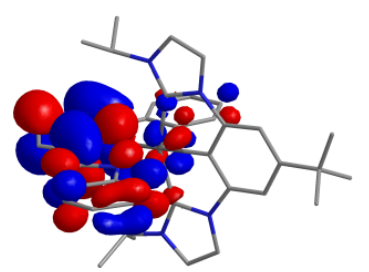

LUMO $(-1.26 \mathrm{eV})$ Ir (4), CCC (2), NNC (94)

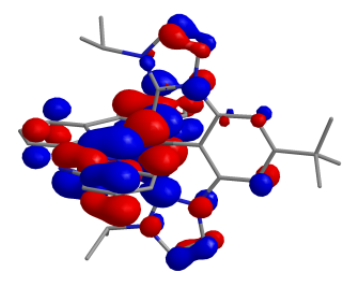

HOMO $(-4.96 \mathrm{eV})$ Ir (31), CCC (17), NNC (51)

5
Figure 3. Frontier molecular orbitals for the ground state $S_{0}$ of complexes 4 and 5 in THF. The contributions (\%) from the iridium and the $C, C, C$ and $N, N, C$ ligands are given in parenthesis. 
Table 2. Electrochemical and DFT MO Energy Data for Complexes 4 and 5

\begin{tabular}{lllllll}
\hline complex & $\begin{array}{l}E_{1 / 2} \text { oxa } \\
(\mathrm{V})\end{array}$ & $\begin{array}{l}E^{\mathrm{ed} a} \\
(\mathrm{~V})\end{array}$ & $\begin{array}{l}E_{1 / 2}{ }^{\mathrm{ox}}-E^{\mathrm{ed}} \\
(\mathrm{V})\end{array}$ & $\begin{array}{l}\mathrm{HOMO}^{b} \\
(\mathrm{eV})\end{array}$ & $\begin{array}{l}\mathrm{LUMO}^{b} \\
(\mathrm{eV})\end{array}$ & $\begin{array}{l}\mathrm{HLG}^{b, c} \\
(\mathrm{eV})\end{array}$ \\
\hline 4 & 0.23 & -2.70 & 2.93 & -4.93 & -1.09 & 3.84 \\
5 & 0.23 & -2.60 & 2.83 & -4.96 & -1.26 & 3.70
\end{tabular}

${ }^{a}$ Measured in degassed acetonitrile solution $\left(1 \times 10^{-3} \mathrm{M}\right) /\left[\mathrm{Bu}_{4} \mathrm{~N}\right] \mathrm{PF}_{6}(0.1 \mathrm{M})$, vs $\mathrm{Fc} / \mathrm{Fc}^{+}$at $0.1 \mathrm{~V} \cdot \mathrm{s}^{-1}$, at room temperature. ${ }^{b}$ Values from electronic structure DFT calculations. ${ }^{c} \mathrm{HLG}=\mathrm{LUMO}-\mathrm{HOMO}$.

At room temperature, the spectra of $\mathbf{5}$ show a very broad band, while a similar spectrum to that of 4 is observed in MeTHF at $77 \mathrm{~K}$. The replacement of the imidazolate unit in the $N, N, C$ - ligand by a benzimidazolate one produces a slight red shift of the emission wavelength in agreement with the smaller HOMO $\rightarrow$ LUMO energy gap in 5. The calculated $S_{0} \rightarrow T_{1}$ wavelengths of $461 \mathrm{~nm}$ for 4 and $470 \mathrm{~nm}$ for 5 are consistent with the corresponding onsets in the phosphorescence spectra, and are mainly assigned to HOMO $\rightarrow$ LUMO (33\% (4) and 68\% (5)) and HOMO $\rightarrow$ LUMO +1 (35\% (4) and 15\% (5)) transitions. Thus, the emissions can be attributed to $\mathrm{T}_{1}$ excited states described as being of mixed MLCT (19\% (4) and 27\% (5))/LC/LLCT character. According to this, the experimental emission wavelengths agree with those calculated by estimating the difference in energy between the optimized triplet states $T_{1}$ and the singlet states with the same geometry in THF. Figure 5 shows the spin density distribution calculated for the $T_{1}$ states at their minimum energy geometries. The observed lifetimes lay in the range $1.2-11.7 \mu \mathrm{s}$, whereas the quantum yields are between 0.73 and 0.49 . In a dopped PMMA film at $5 \mathrm{wt}$ $\%$, the quantum yield of 4 (0.73) is significantly higher than that of 5 (0.49). Nevertheless in MeTHF solution, at room temperature, the quantum yields of both emitters are similar (about 0.60 ). The radiative and nonradiative rate constants are similar for the two compounds both in PMMA film and in solution. Dicarbene pincer iridium(III) complexes bearing a dianion derived from 6-pyrazolyl2-phenylpyridines show blue shifted emissions with regard to those of 4 and $5{ }^{17}$

Electroluminiscence Properties of an OLED Device Based on 5. In order to evaluate this class of [ $\left.5 t+4 t^{\prime}\right]$ complexes as emitters in OLEDs, we have compared an OLED device based on complex 5 with another one based on the homoleptic tris(bidentate) fac$\operatorname{Ir}(\text { ppy })_{3}$ (Hppy $=2$-phenylpyridine $){ }^{23}$ which is one of the most successful green-triplet emitters in the field of OLED display technology. ${ }^{2}$ The performance of the emitters has been tested in bottom emission structure. The devices were fabricated by high vacuum $\left(<10^{-7}\right.$ Torr $)$ thermal evaporation. Under the same conditions, complex 4 decompose. Both complexes 4 and 5 were subjected to differential scanning calorimetry (DSC) and thermogravimetric analysis (TGA). The 5\% weight loss temperature from TGA is similar between compound $4\left(348^{\circ} \mathrm{C}\right)$ and $5\left(353^{\circ} \mathrm{C}\right)$. However; the endothermic peak for compound $4\left(375{ }^{\circ} \mathrm{C}\right)$ is significantly lower than that of compound $5\left(412^{\circ} \mathrm{C}\right)$ from DSC analysis; which might account for its decomposition upon sublimation. Both devices were encapsulated with a glass lid sealed with an epoxy resin in a nitrogen filled glove box $\left(<1 \mathrm{ppm}\right.$ of $\mathrm{H}_{2} \mathrm{O}$ and $\left.\mathrm{O}_{2}\right)$ immediately after fabrication, and a moisture getter was incorporated inside the package. The schematic devices structure including the chemical structures of the devices materials and their relative energy levels are depicted in Figure 6. The devices consist in an anode electrode of indium tin oxide (ITO; $750 \AA$ ); a hole injection layer (HIL; $100 \AA)$ of dipyrazino[2,3- $\left.f 2^{\prime}, 3^{\prime}-h\right]$-quinoxaline-

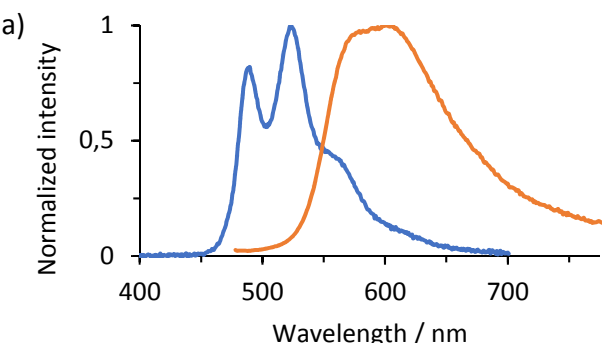

b)

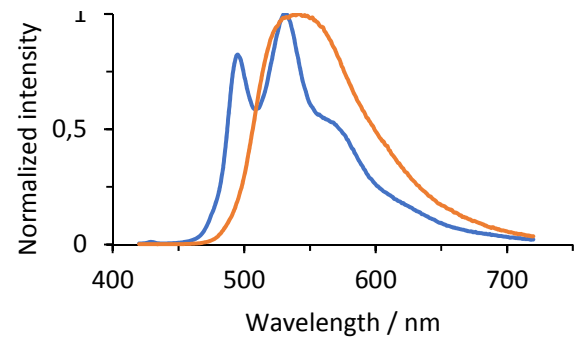

c)

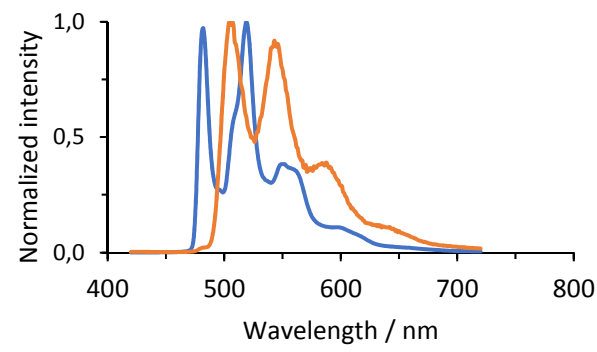

Figure 4. Emission spectra of complexes 4 (blue line) and 5 (orange line) recorded in 5 wt \% PMMA films at $298 \mathrm{~K}$ (a), in MeTHF at $298 \mathrm{~K}$ (b), and in MeTHF at 77K (c).

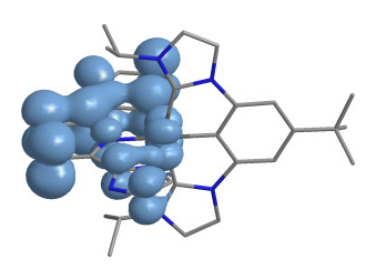

4

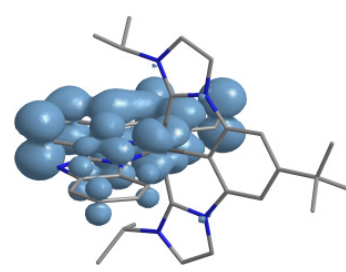

5
Figure 5. DFT calculated spin density of 4 and 5 at 0.002 au contour level.

2,3,6,7,10,11-hexacarbonitrile (HAT-CN); a hole transporting layer (HTL; $450 \AA)$ of $N, N^{\prime}$-bis(naphthalen-1-yl)- $N, N^{\prime}$ bis(phenyl)benzidine (NPD); an emissive layer (EML; $350 \AA$ ) containing 4-(3-(triphenylen-2-yl)phenyl)dibenzo[ $b, d]$ thiophene (H1) as a host doped with either 5 or the comparative complex $\operatorname{Ir}(\text { ppy })_{3}$ as the emitter $(10 \%)$; a hole blocking layer of H1 (HBL; $50 \AA), \mathrm{Alq}_{3}$ as electron transporting layer (ETL; $450 \AA$ ); $\mathrm{LiF}$ as electron injection layer (EIL; $10 \AA$ ); and aluminum as cathode $(1000 \AA)$. As shown in Figure 6, the HOMO/LUMO levels of $5.14 /-2.15 \mathrm{eV}$ for 5 and $-5.11 /-2.10 \mathrm{eV}$ for $\operatorname{Ir}(\text { ppy })_{3}$, obtained from the electrochemical data, are within the HOMO/LUMO energy levels of the host material.

The performance data of the devices are collected in Table 4 and Figure 7. The electroluminescence spectrum (EL) of compound 5 device shows a maximum at a wavelength of $552 \mathrm{~nm}$ which is con- 
Table 3. Photophysical Data for Complexes 4 and 5

\begin{tabular}{|c|c|c|c|c|c|c|c|c|c|}
\hline complex & $\begin{array}{l}\text { calcd } \lambda_{\mathrm{em}}{ }^{a} \\
(\mathrm{~nm})\end{array}$ & media $(T, \mathrm{~K})$ & $\lambda_{\mathrm{em}}(\mathrm{nm})$ & $\lambda_{\text {exc }}(\mathrm{nm})$ & $\tau(\mu \mathrm{s})$ & $\phi$ & $\mathrm{k}_{\mathrm{r}}^{\mathrm{b}}\left(\mathrm{s}^{-1}\right)$ & $\mathrm{k}_{\mathrm{nr}}^{\mathrm{b}}\left(\mathrm{s}^{-1}\right)$ & $\mathrm{k}_{\mathrm{r}} / \mathrm{k}_{\mathrm{nr}}$ \\
\hline \multirow[t]{3}{*}{4} & \multirow{3}{*}{537} & PMMA (298) & $490,525(\max ), 560(\mathrm{sh})$ & 390 & 2.1 & 0.73 & $3.5 \times 10^{5}$ & $1.3 \times 10^{5}$ & 2.7 \\
\hline & & MeTHF (298) & 496,531 (max), $567(\mathrm{sh})$ & 397 & 1.2 & 0.60 & $5.0 \times 10^{5}$ & $3.3 \times 10^{5}$ & 1.5 \\
\hline & & MeTHF (77) & $482,520(\max ), 550(\mathrm{sh})$ & 397 & 5.9 & & & & \\
\hline \multirow[t]{3}{*}{5} & \multirow{3}{*}{528} & PMMA (298) & 590 & 364 & 4.1 & 0.49 & $1.2 \times 10^{5}$ & $1.2 \times 10^{5}$ & 1.0 \\
\hline & & MeTHF (298) & 542 & 372 & 4.1 & 0.56 & $1.4 \times 10^{5}$ & $1.1 \times 10^{5}$ & 1.3 \\
\hline & & MeTHF (77) & $506(\max ), 543,585(\mathrm{sh})$ & 371 & 11.7 & & & & \\
\hline
\end{tabular}

${ }^{a}$ Predicted from TD-DFT calculations in THF at $298 \mathrm{~K}$ by estimating the energy difference between the optimized $\mathrm{T}_{1}$ and singlet state with the same geometry . ${ }^{b}$ Calculated according to the equations $k_{\mathrm{r}}=\phi / \tau$ and $k_{\mathrm{nr}}=(1-\phi) / \tau$, where $k_{\mathrm{r}}$ is the radiative rate constant, $k_{\mathrm{nr}}$ is the nonradiative rate constant, $\phi$ is the quantum yield, and $\tau$ is the excited-state observed lifetime

Table 4. Summary of the Performances of the Devices Based on 5 and $\operatorname{Ir}(\mathrm{ppy})_{3}$

\begin{tabular}{|c|c|c|c|c|c|c|c|c|c|}
\hline \multirow[b]{2}{*}{$\begin{array}{l}\text { emitter } \\
(10 \%)\end{array}$} & \multirow[b]{2}{*}{$\begin{array}{l}\lambda_{\max } \\
(\mathrm{nm})\end{array}$} & \multirow[b]{2}{*}{$\begin{array}{l}\text { fwhm }^{a} \\
(\mathrm{~nm})\end{array}$} & \multicolumn{2}{|c|}{$1931 \mathrm{CIE}$} & \multirow[b]{2}{*}{$\begin{array}{l}\max \mathrm{EQE}^{b} \\
(\%)\end{array}$} & \multicolumn{4}{|c|}{ at $1000 \mathrm{~cd} / \mathrm{m}^{2}$} \\
\hline & & & CIE $x$ & CIE y & & $\begin{array}{l}\text { voltage } \\
(\mathrm{V})\end{array}$ & $\begin{array}{l}\text { EQE } \\
(\%)\end{array}$ & $\begin{array}{l}\mathrm{LE}^{c} \\
(\mathrm{~cd} / \mathrm{A})\end{array}$ & $\begin{array}{l}\mathrm{PE}^{d} \\
(\mathrm{~lm} / \mathrm{W} \\
)\end{array}$ \\
\hline 5 & 552 & 85 & 0.458 & 0.530 & 12.0 & 8.0 & 9.3 & 28.8 & 11.3 \\
\hline $\operatorname{Ir}(\mathrm{ppy})_{3}$ & 518 & 68 & 0.304 & 0.6301 & 14.3 & 5.8 & 13.1 & 46.9 & 25.5 \\
\hline
\end{tabular}

${ }^{a}$ Full width at half-maximum of the emission peak in the electroluminescence spectrum. ${ }^{b}$ External quantum efficiency.

'Luminous efficacy. ${ }^{\circledR}$ Power efficacy.

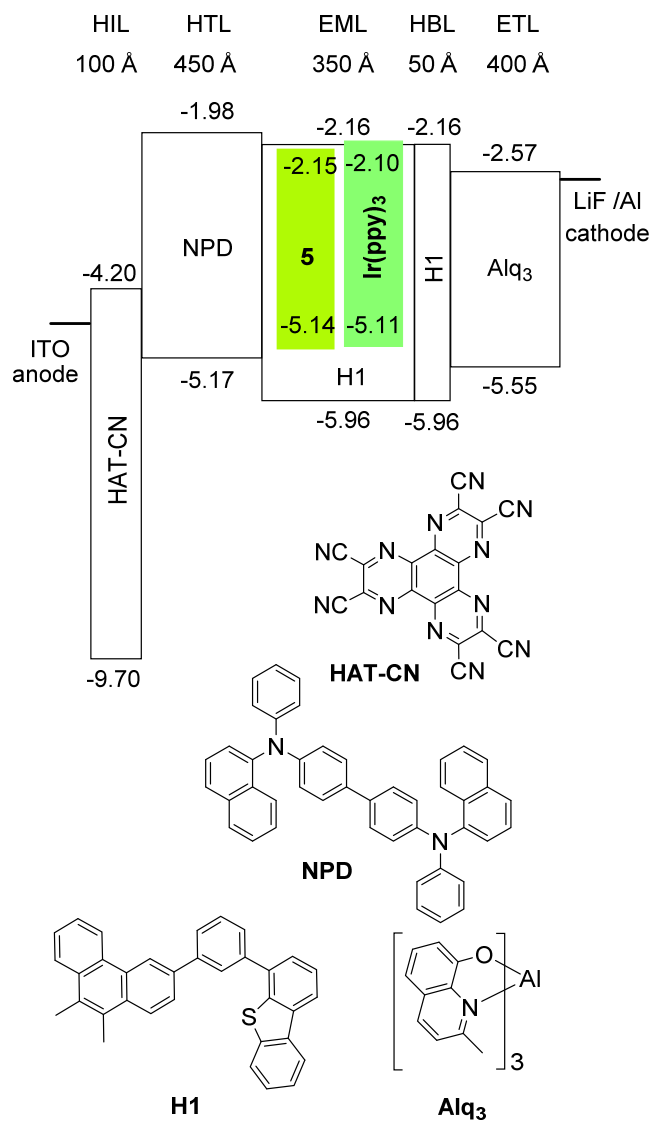

Figure 6. OLED scheme showing the energy levels of the materials (in $\mathrm{eV})$ and chemical structures of the compounds used in the devices. sistent with the photoluminescence (PL) measurements. It is 34 $\mathrm{nm}$ red shifted and $17 \mathrm{~nm}$ broader with regard to that of comparative compound $\operatorname{Ir}(\mathrm{ppy})_{3}$ (Figure $7 \mathrm{a}$ ). The overall performance of the device based on 5 is poorer than that of comparative device. Thus, the turn-on voltage of these devices is around $5 \mathrm{~V}(5)$ and 4 $\mathrm{V}\left(\operatorname{Ir}(\mathrm{ppy})_{3}\right)$, whereas at $8.0 \mathrm{~V}(5)$ and $5.8 \mathrm{~V}\left(\operatorname{Ir}(\mathrm{ppy})_{3}\right)$ the luminance reaches $1000 \mathrm{~cd} / \mathrm{m}^{2}$ (Figure 7c). At this brightness, external quantum efficiency (EQE) of $9.3 \%(5)$ versus $13.1 \%\left(\operatorname{Ir}(\mathrm{ppy})_{3}\right)$ is achieved (Table 4). This is consistent with the lower photoluminescence quantum yield $(\phi)$ of complex $5(0.49-0.56)$ versus $\operatorname{Ir}(\text { ppy })_{3}(0.97) .{ }^{23}$ Complex 5 revealed a $12 \%$ maximum EQE compared to $14.3 \%$ for $\operatorname{Ir}(\text { ppy })_{3}$ (Figure $7 \mathrm{~d}$ ). Similarly, the luminous efficacy (LE; Figure $7 \mathrm{e}$ ) and power efficacy (PE; Figure $7 \mathrm{f}$ ) are also lower for the device containing 5 as emitter. Thus, at a luminance of $1000 \mathrm{~cd} / \mathrm{m}^{2}$ the device based on 5 showed LE of $28.8 \mathrm{~cd} / \mathrm{A}$ and PE of $11.3 \mathrm{~lm} / \mathrm{W}$ versus $46.9 \mathrm{~cd} / \mathrm{A}$ and $25.5 \mathrm{~lm} / \mathrm{W}$ for the comparative device.

\section{CONCLUDING REMARKS}

This study shows a straightforward procedure to prepare $[\operatorname{IrI}(\mu$ I) $(5 \mathrm{t})]_{2}$ dimers, based on 1,3-bis(NHC)-phenyl pincer ligands $(5 \mathrm{t})$. Treatment of the methoxide dimer $\left[\operatorname{Ir}(\mu \text {-OMe })\left(\eta^{4}-\mathrm{COD}\right)\right]_{2}$ with the corresponding bis(imidazolium) salt in the presence of KI, and in the absence of any base, directly leads to the desired compound. These dimers are certainly useful starting complexes to synthetize bis(tridentate) $\left[5 t+4 t^{\prime}\right]$ derivatives, where the $4 \mathrm{t}^{\prime}$ pincer ligand bears a 2-pyridyl-imidazolate, or 2-pyridylbenzimidazolate, moiety. The new $\left[5 t+4 \mathrm{t}^{\prime}\right]$ compounds are green and greenish yellow emitters upon photoexcitation in PMMA film and in MeTHF solution, with quantum yields between 0.73 and 0.49 . The new emitters prove to have applicability to the fabrication of OLED devices. Thus, the OLED with 5 as the emitter $\left(\lambda_{\max }\right.$ $=552 \mathrm{~nm}$ ) 

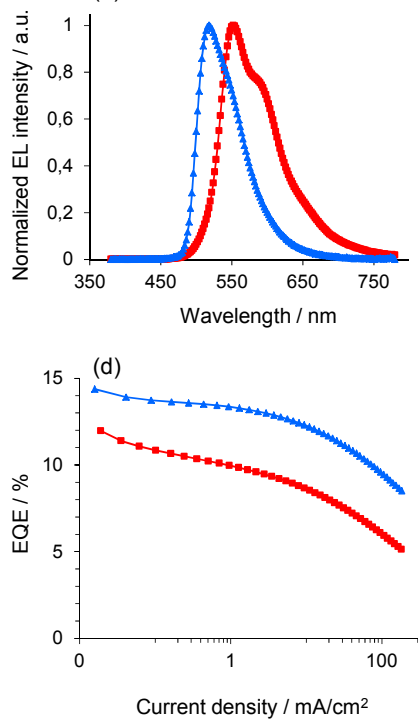

(b)

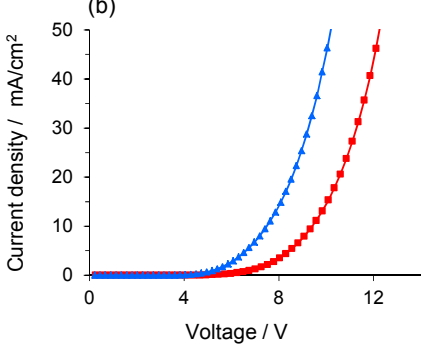

(e)

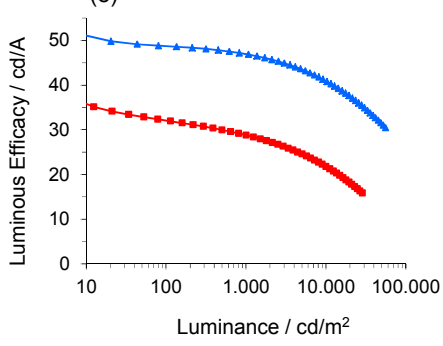

(c)

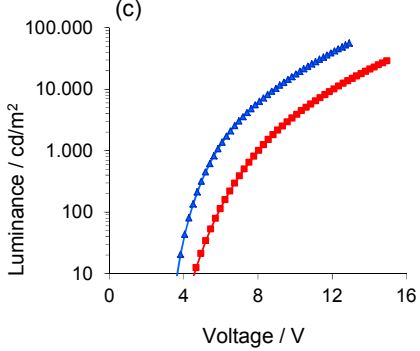

(f)

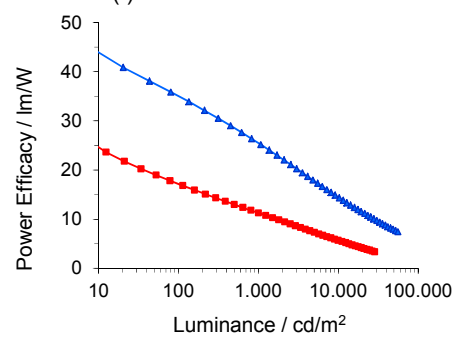

Figure 7. Plots of (a) EL spectra, (b) $J$ versus $V$, (c) $L$ versus V, (d) EQE versus $J$, (e) LE vs $L$, and (f) PE versus $L$ for the OLED devices based on complex $\mathbf{5}$ (red $\mathbf{a}$ ) and comparative derivative $\operatorname{Ir}(\text { ppy) })_{3}$ (blue $\boldsymbol{\Lambda}$ ).

revealed $12 \% \max \mathrm{EQE}$, which is consistent with emitter's photoluminescence quantum yield.

In summary, a straightforward high yield synthetic route to prepare phosphorescent $\left[5 t+4 t^{\prime}\right] \operatorname{Ir}($ III) molecules with applicability to the fabrication of OLED devices is described.

\section{EXPERIMENTAL SECTION}

General Information. All the reactions were carried out under argon using dried solvents and Schlenk-tube techniques. Instrumental methods, Xray information, and DFT computational details are provided in the Supporting Information. $\left[\operatorname{Ir}(\mu \text {-OMe })\left(\eta^{4} \text {-COD }\right)\right]_{2}(1),{ }^{24}$ 5-tert-butyl-1,3-bis (3isopropylimidazolium $)$ benzene diiodide, ${ }^{17 a} \quad$ 2-( $1 H$-imidazol-2-yl)-6phenylpyridine, ${ }^{25}$ and 2-(1H-benzimidazol-2-yl)-6-phenylpyridine ${ }^{26}$ were prepared by previously published methods. In the NMR spectra, chemical shifts (expressed in parts per million) are referenced to residual solvent peaks and coupling constants $(J)$ are given in hertz.

Preparation of $\left[\operatorname{IrI}(\boldsymbol{\mu}-\mathrm{I})\left\{\boldsymbol{\kappa}^{3}-C, C, C\right.\right.$-[ $\left.\left.\left.{ }^{\mathrm{P}} \mathrm{PrImC}_{6} \mathrm{H}_{2}\left(5-{ }^{\mathrm{t}} \mathrm{Bu}\right) \operatorname{Im}^{\mathrm{i}} \mathrm{Pr}\right]\right\}\right]_{2}(2)$. A mixture of $1 \quad(300 \quad \mathrm{mg}, \quad 0.452 \mathrm{mmol}), \quad$ 5-tert-butyl-1,3-bis(3isopropylimidazolium) benzene diiodide $(548.7 \mathrm{mg}, 0.905 \mathrm{mmol})$, and $\mathrm{KI}$ $(750 \mathrm{mg}, 4.526 \mathrm{mmol})$ in 2-ethoxyethanol $(23 \mathrm{~mL})$ was heated at $120{ }^{\circ} \mathrm{C}$ for $18 \mathrm{~h}$. After cooling to room temperature, the solvent was removed under vacuum and the resulting brown solid was washed with methanol $(6 \times 12$ $\mathrm{mL})$ and diethyl ether $(3 \times 10 \mathrm{~mL})$ and dried under vacuum. Yield: $340 \mathrm{mg}$ (0.213 mmol, 47\%). Anal. Calcd for $\mathrm{C}_{44} \mathrm{H}_{58} \mathrm{I}_{4} \mathrm{I}_{2} \mathrm{~N}_{8}: \mathrm{C}, 33.22 ; \mathrm{H}, 3.67 ; \mathrm{N}$, 7.04. Found: C, 31.89; H, 3.53; N, 6.87 .

Preparation of $\operatorname{IrI}_{2}\left\{\boldsymbol{\kappa}^{3}-C, C, C\right.$ - $\left.\left[{ }^{\mathrm{P} r I m C} \mathrm{C}_{6} \mathrm{H}_{2}(5-\mathrm{B} \mathrm{Bu}) \mathrm{Im}^{\mathrm{i}} \mathrm{Pr}\right]\right\}\left(\mathrm{CH}_{3} \mathrm{CN}\right)(3)$. A suspension of $2(100 \mathrm{mg}, 0.063 \mathrm{mmol})$ in acetonitrile $(20 \mathrm{~mL})$ was refluxed overnight. The solvent was concentred and $15 \mathrm{~mL}$ of diethyl ether were added. The resulting pale-green solid was washed with diethyl ether $(3 \times 5 \mathrm{~mL})$ and dried under vacuum. Yield: $91.3 \mathrm{mg}(0.109 \mathrm{mmol}, 86.8 \%)$. $\mathrm{X}$-ray quality crystals were grown by slow evaporation of an acetonitrile solution of 3 at $277 \mathrm{~K}$. Anal. Calcd for $\mathrm{C}_{24} \mathrm{H}_{32} \mathrm{I}_{2} \mathrm{IrN}_{5}: \mathrm{C}, 34.46 ; \mathrm{H}, 3.86$; N, 8.37. Found: C, $34.19 ; \mathrm{H}, 3.81 ; \mathrm{N}, 8.50$. HRMS (electrospray, $\mathrm{m} / \mathrm{z}$ ): Calcd for $\mathrm{C}_{22} \mathrm{H}_{29} \mathrm{I}_{2} \mathrm{IrN}_{4} \mathrm{Na}\left[\mathrm{M}-\mathrm{CH}_{3} \mathrm{CN}+\mathrm{Na}\right]^{+}$: 819.0003; found 818.9981. ${ }^{1} \mathrm{H}$ $\operatorname{NMR}\left(300 \mathrm{MHz}, \mathrm{CD}_{2} \mathrm{Cl}_{2}, 298 \mathrm{~K}\right): 7.63\left(\mathrm{~d},{ }^{3}{ }_{\mathrm{H}-\mathrm{H}}=2.1,2 \mathrm{H}, \mathrm{CH} \mathrm{Im}\right), 7.18$ $\left(\mathrm{d},{ }^{3} \mathrm{H}_{\mathrm{H}-\mathrm{H}}=2.1,2 \mathrm{H}, \mathrm{CH} \mathrm{Im}\right), 7.18(\mathrm{~s}, 2 \mathrm{H}, \mathrm{Ph}), 5.12\left(\mathrm{sept}, 2 \mathrm{H},{ }^{3}{ }_{\mathrm{H}-\mathrm{H}}=6.8\right.$,
$\left.\mathrm{CH}^{\mathrm{i}} \mathrm{Pr}\right), 2.64\left(\mathrm{~s}, 3 \mathrm{H}, \mathrm{CH}_{3} \mathrm{CN}\right), 1.67\left(\mathrm{~d}, 12 \mathrm{H},{ }^{3} \mathrm{H}_{\mathrm{H}-\mathrm{H}}=6.8, \mathrm{CH}_{3}{ }^{\mathrm{i}} \mathrm{Pr}\right), 1.45(\mathrm{~s}$, $\left.9 \mathrm{H},{ }^{\mathrm{B}} \mathrm{Bu}\right) \cdot{ }^{13} \mathrm{C}\left\{{ }^{1} \mathrm{H}\right\}$ NMR $\left(100 \mathrm{MHz}, \mathrm{CD}_{2} \mathrm{Cl}_{2}, 298 \mathrm{~K}\right): \delta 163.7$ (Ir-C, NCN $\mathrm{Im}), 147.1\left(\mathrm{C}_{q}, \mathrm{Ph}\right), 145.8\left(\mathrm{C}_{q}, \mathrm{Ph}\right), 130.4(\mathrm{Ir}-\mathrm{C}, \mathrm{Ph}$; this signal is not observed in the ${ }^{13} \mathrm{C}$ APT, but can be assigned based on the ${ }^{1} \mathrm{H}-{ }^{13} \mathrm{C}$ HMBC experiment), $116.5(\mathrm{CH}, \mathrm{Im}), 115.9(\mathrm{CH}, \mathrm{Im}), 105.0(\mathrm{CH} \mathrm{Ph}), 52.1(\mathrm{CH}$, $\left.{ }^{\mathrm{i}} \mathrm{Pr}\right), 35.4\left(\mathrm{C}_{q},{ }^{\mathrm{t}} \mathrm{Bu}\right), 32.5\left(\mathrm{CH}_{3},{ }^{\mathrm{t}} \mathrm{Bu}\right), 23.8\left(\mathrm{CH}_{3},{ }^{\mathrm{i}} \mathrm{Pr}\right), 3.8\left(\mathrm{CH}_{3}, \mathrm{CH}_{3} \mathrm{CN}\right)$; the $\mathrm{C}_{4}$ of $\mathrm{CH}_{3} \mathrm{CN}$ could not be observed.

Preparation of $\operatorname{Ir}\left\{\boldsymbol{\kappa}^{3}-C, C, C-\left[{ }^{\mathrm{i}} \operatorname{PrImC} \mathrm{C}_{6} \mathrm{H}_{2}\left(5-{ }^{\mathrm{t}} \mathrm{Bu}\right) \operatorname{Im}^{\mathrm{i}} \mathrm{Pr}\right]\right\}\left\{\boldsymbol{\kappa}^{3}-N, N, C-\right.$ [NImpyC $\left.\left.{ }_{6} \mathrm{H}_{4}\right]\right\}$ (4). A mixture of $2(150 \mathrm{mg}, 0.094 \mathrm{mmol}), 2-(1 \mathrm{H}-$ imidazol-2-yl)-6-phenylpyridine ( $41.7 \mathrm{mg}, 0.188 \mathrm{mmol}$ ), and $\mathrm{Na}_{2} \mathrm{CO}_{3}(50$ $\mathrm{mg}, 0.472 \mathrm{mmol})$ in 2-ethoxyethanol $(17 \mathrm{~mL})$, was heated at $120^{\circ} \mathrm{C}$ for 20 h. After cooling to room temperature, the solvent was removed under vacuum and the resulting solid was purified by $\mathrm{SiO}_{2}$ (230-400 mesh) column chromatography $\left(\mathrm{CH}_{2} \mathrm{Cl}_{2} / \mathrm{MeOH}(5 \%)\right)$. The solvent was removed and the resulting orange solid was washed with diethyl ether $(3 \times 10$ $\mathrm{mL})$ and dried under vacuum. Yield: $99 \mathrm{mg}(0.130 \mathrm{mmol}, 69 \%)$. X-ray quality crystals were grown by slow diffusion of diethyl ether into a dichloromethane solution of 4 at $277 \mathrm{~K}$. Anal. Calcd for $\mathrm{C}_{36} \mathrm{H}_{38} \mathrm{IrN} \mathrm{IN}_{7} \cdot \mathrm{C}_{4} \mathrm{H}_{10} \mathrm{O}$ : C, 57.53; H, 5.79; N, 11.74. Found: C, 57.19; H, 5.57; N, 11.70. HRMS (electrospray, $m / z$ ): Calcd for $\mathrm{C}_{36} \mathrm{H}_{39} \mathrm{IrN}_{7}[\mathrm{M}+\mathrm{H}]^{+}$762.2892; found 762.2928. ${ }^{1} \mathrm{H}$ NMR $\left(400 \mathrm{MHz}, \mathrm{CD}_{2} \mathrm{Cl}_{2}, 298 \mathrm{~K}\right): \delta 9.04\left(\mathrm{dd},{ }^{3} J_{\mathrm{H}-\mathrm{H}}=8.0,{ }^{4} J_{\mathrm{H}-}\right.$ $\mathrm{H}=1.0,1 \mathrm{H}, \mathrm{py}), 8.04\left(\mathrm{dd},{ }^{3} \mathrm{H}_{\mathrm{H}-\mathrm{H}}={ }^{3} \int_{\mathrm{H}-\mathrm{H}}=8.0,1 \mathrm{H}, \mathrm{py}\right), 7.97\left(\mathrm{dd},{ }^{3} \mathrm{H}_{\mathrm{H} \cdot \mathrm{H}}=8.0\right.$, $\left.{ }^{4} J_{\mathrm{H}-\mathrm{H}}=1.0,1 \mathrm{H}, \mathrm{py}\right), 7.67\left(\mathrm{dd},{ }^{3} \int_{\mathrm{H}-\mathrm{H}}=7.7,{ }^{4}{ }_{\mathrm{H}-\mathrm{H}}=1.4,1 \mathrm{H}, P h-\mathrm{py}\right), 7.62(\mathrm{~d}$, $\left.{ }^{3} J_{\mathrm{H}-\mathrm{H}}=2.2,2 \mathrm{H}, I m-\mathrm{Pr}\right), 7.38(\mathrm{~s}, 2 \mathrm{H}, P h-\mathrm{Bu}), 7.17\left(\mathrm{~d},{ }^{3} J_{\mathrm{H}-\mathrm{H}}=1.4,1 \mathrm{H}, I m-\right.$ py), $6.81\left(\mathrm{ddd},{ }^{3} \mathrm{H}_{\mathrm{H}-\mathrm{H}}=7.7,{ }^{3} \mathrm{H}_{\mathrm{H}-\mathrm{H}}=7.4,{ }^{4}{ }_{\mathrm{H}-\mathrm{H}}=1.3,1 \mathrm{H}, P h-\mathrm{py}\right), 6.77\left(\mathrm{~d},{ }^{3}{ }_{\mathrm{H}-\mathrm{H}}\right.$ $=2.2,2 \mathrm{H}, I m-\operatorname{Pr}), 6.57\left(\mathrm{ddd},{ }^{3} \mathrm{H}-\mathrm{H}=7.7,{ }^{3}{ }_{\mathrm{H}-\mathrm{H}}=7.4,{ }^{4} \mathrm{H}_{\mathrm{H}-\mathrm{H}}=1.4,1 \mathrm{H}, P h-\mathrm{py}\right.$, $6.39\left(\mathrm{~d},{ }^{3} \mathrm{H}_{\mathrm{H}-\mathrm{H}}=1.4,1 \mathrm{H}, I m-\mathrm{py}\right), 5.85\left(\mathrm{dd},{ }^{3} J_{\mathrm{H}-\mathrm{H}}=7.5,{ }^{4} \mathrm{H}_{\mathrm{H}-\mathrm{H}}=0.9,1 \mathrm{H}, \mathrm{Ph} P h-\right.$ py), $3.04\left(\right.$ sept, ${ }^{3} \mathrm{H}_{\mathrm{H}-\mathrm{H}}=6.8,2 \mathrm{H}, \mathrm{CH}{ }^{\mathrm{i}} \mathrm{Pr}$ ), $1.55\left(\mathrm{~s}, 9 \mathrm{H},{ }^{\mathrm{B}} \mathrm{Bu}\right.$ ), 0.79, 0.70 (both d, ${ }^{3}{ }_{\mathrm{H}-\mathrm{H}}=6.8,6 \mathrm{H}$ each, $\left.\mathrm{CH}_{3}{ }^{\mathrm{i}} \mathrm{Pr}\right) .{ }^{13} \mathrm{C}\left\{{ }^{1} \mathrm{H}\right\} \mathrm{NMR}\left(100 \mathrm{MHz}, \mathrm{CD}_{2} \mathrm{Cl}_{2}, 298\right.$ K): $\delta 164.6$ (NC, py), 164.4 (Ir-C, NCN Im-Pr), 150.0 (NCN, Im-py), 146.8 (NC, py $\left.+\mathrm{C}_{\mathrm{y}}, P h^{-\mathrm{B}} \mathrm{Bu}\right), 145.0\left(\mathrm{NC}, P h^{\mathrm{t}} \mathrm{Bu}\right), 144.0$ (Ir-C, $P h_{-}{ }^{-\mathrm{BBu}}+$ $\mathrm{C}_{q}, P h$-py), 142.7 (Ir-C $\mathrm{I}_{\mathrm{q}}, P h$-py), 138.2 (CH, py), 135.4 (CH, Ph-py), 130.9 (CH, Im-py), 130.3, 125.4, 121.4 (all CH, Ph-py), 119.8 (CH, Impy), 118.8, 117.1 (both $\mathrm{CH}$, py), 116.4, 115.8 (both $\mathrm{CH}, \mathrm{Im}$ - $\mathrm{Pr}$ ), 105.4 $\left(\mathrm{CH}, P h^{\mathrm{t}} \mathrm{Bu}\right), 51.1\left(\mathrm{CH},{ }^{\mathrm{i}} \mathrm{Pr}\right), 35.8\left(\mathrm{C}_{\vartheta},{ }^{\mathrm{t}} \mathrm{Bu}\right), 32.4\left(\mathrm{CH}_{3},{ }^{\mathrm{t}} \mathrm{Bu}\right), 23.6,23.4$ (both $\mathrm{CH}_{3},{ }^{,} \mathrm{Pr}$ ).

Preparation of $\operatorname{Ir}\left\{\boldsymbol{r}^{3}-C, C, C-\left[{ }^{\mathrm{P}} \mathrm{PrImC} \mathrm{C}_{6} \mathrm{H}_{2}\left(5-{ }^{\mathrm{t}} \mathrm{Bu}\right) \operatorname{Im}^{\mathrm{i}} \mathrm{Pr}\right]\right\}\left\{\boldsymbol{r}^{3}-N, N, C\right.$ [NBzimpyC $\left.\left.{ }_{6} \mathrm{H}_{4}\right]\right\}$ (5). This compound was prepared as described for 4 , 
starting from 2 (150 mg, $0.094 \mathrm{mmol}), 2$-(1H-benzimidazol-2-yl)-6phenylpyridine ( $51.1 \mathrm{mg}, 0.188 \mathrm{mmol})$, and $\mathrm{Na}_{2} \mathrm{CO}_{3}(50 \mathrm{mg}, 0.472 \mathrm{mmol})$ and heating for $24 \mathrm{~h}$. Orange solid. Yield: $83 \mathrm{mg}$ (0.102 mmol, 54.2\%). Anal. Calcd for $\mathrm{C}_{40} \mathrm{H}_{40} \mathrm{IrN}_{7}$ : C, 59.24; H, 4.97; N, 12.09. Found: C, 59.40; $\mathrm{H}, 5.14 ; \mathrm{N}, 12.30$. HRMS (electrospray, $\mathrm{m} / \mathrm{z}$ ): calcd for $\mathrm{C}_{40} \mathrm{H}_{41} \mathrm{IrN}_{7}$ $[\mathrm{M}+\mathrm{H}]^{+}$812.3052; found 812.3019. ${ }^{1} \mathrm{H} \mathrm{NMR}\left(400 \mathrm{MHz}, \mathrm{CD}_{2} \mathrm{Cl}_{2}, 298 \mathrm{~K}\right)$ : $\delta 8.79(\mathrm{br}, 1 \mathrm{H}, \mathrm{py}), 8.01(\mathrm{~m}, 2 \mathrm{H}, \mathrm{py}), 7.74\left(\mathrm{dd},{ }^{3} J_{\mathrm{H}-\mathrm{H}}=7.8,{ }^{4} J_{\mathrm{H}-\mathrm{H}}=0.9,1 \mathrm{H}\right.$, Ph-py), $7.64\left(\mathrm{~d},{ }^{3} J_{\mathrm{H}-\mathrm{H}}=7.6,1 \mathrm{H}\right.$, Bzim $), 7.62\left(\mathrm{~d}, 33_{\mathrm{H}-\mathrm{H}}=2.1,2 \mathrm{H}, \mathrm{Im}\right), 7.46(\mathrm{~s}$, $\left.2 \mathrm{H}, P h{ }^{\mathrm{t}} \mathrm{Bu}\right), 7.07\left(\mathrm{dd},{ }^{3} J_{\mathrm{H}-\mathrm{H}}={ }^{3} J_{\mathrm{H}-\mathrm{H}}=7.6,1 \mathrm{H}, \mathrm{Bzim}\right), 6.85\left(\mathrm{dd},{ }^{3} J_{\mathrm{H}-\mathrm{H}}=7.8\right.$, $\left.{ }^{3} J_{\mathrm{H}-\mathrm{H}}=7.6,{ }^{4} J_{\mathrm{H}-\mathrm{H}}=0.8,1 \mathrm{H}, P h-\mathrm{py}\right), 6.79\left(\mathrm{dd},{ }^{3} J_{\mathrm{H}-\mathrm{H}}={ }^{3} J_{\mathrm{H}-\mathrm{H}}=7.6,1 \mathrm{H}, \mathrm{Bzim}\right)$, $6.70\left(\mathrm{~d},{ }^{3} \int_{\mathrm{H}-\mathrm{H}}=2.1,2 \mathrm{H}, \mathrm{Im}\right), 6.62\left(\mathrm{ddd},{ }^{3} J_{\mathrm{H}-\mathrm{H}}=7.8,{ }^{3} \int_{\mathrm{H}-\mathrm{H}}=7.6,{ }^{4} J_{\mathrm{H}-\mathrm{H}}=0.9\right.$, 1H, Ph-py), 6.09 (d, $\left.{ }^{3} J_{\mathrm{H}-\mathrm{H}}=7.6,1 \mathrm{H}, \mathrm{Bzim}\right), 6.06\left(\mathrm{dd},{ }^{3} J_{\mathrm{H}-\mathrm{H}}=7.6,{ }^{4} J_{\mathrm{H}-\mathrm{H}}=0.8\right.$, $1 \mathrm{H}, \mathrm{Ph}$-py), 3.14 (sept, $\left.{ }^{3} \mathrm{H}_{\mathrm{H}-\mathrm{H}}=6.8,2 \mathrm{H}, \mathrm{CH}{ }^{\mathrm{i}} \mathrm{Pr}\right), 1.62\left(\mathrm{~s}, 9 \mathrm{H},{ }^{\mathrm{t}} \mathrm{Bu}\right), 0.71$, 0.68 (both d, ${ }^{3} J_{\mathrm{H}-\mathrm{H}}=6.8,6 \mathrm{H}$ each, $\mathrm{CH}^{3} \mathrm{Pr}$ ). ${ }^{13} \mathrm{C}\left\{{ }^{1} \mathrm{H}\right\} \mathrm{NMR}(100 \mathrm{MHz}$, $\mathrm{CD}_{2} \mathrm{Cl}_{2}, 298 \mathrm{~K}$ ): $\delta 164.5$ (NC py), 164.2 (Ir-C, NCN Im), $156.9(\mathrm{NCN}$, Bzim), 148.6 (NC, py), $146.2\left(\mathrm{C}_{\mathrm{q}} P h^{-\mathrm{B}} \mathrm{Bu}\right), 144.6$ (NC, $\left.P h{ }^{\mathrm{t}}{ }^{\mathrm{Bu}}\right), 144.5\left(\mathrm{C}_{\mathrm{q}}\right.$, Ph-py), 143.8 (Ir-C, Ph-py), 143.6 (Ir-C Ph- ${ }^{\mathrm{B} u}$ ), 142.9, 137.9 (both $\mathrm{C}_{\mathrm{q}}$, Bzim), 137.2 (CH, py), 135.5, 129.6, 124.8 (all CH, Ph-py), 123.0, 122.6, (both CH, Bzim), 120.7 (CH, Ph-py), 118.5, 116.9 (both CH, py), 116.2, (CH, Bzim), 115.6 (CH, Im), 115.4 (CH, Bzim), 115.0 (CH, Im), 105.4 $\left(\mathrm{CH}, \mathrm{Ph}-{ }^{\mathrm{t}} \mathrm{Bu}\right), 50.3\left(\mathrm{CH},{ }^{\mathrm{i}} \mathrm{Pr}\right), 35.3\left(\mathrm{C}_{\mathrm{q}},{ }^{\mathrm{t}} \mathrm{Bu}\right), 31.9\left(\mathrm{CH}_{3},{ }^{\mathrm{t}} \mathrm{Bu}\right), 23.0,22.9$ (both $\mathrm{CH}_{3}$, ${ }^{\mathrm{i} P r}$ ).

\section{ASSOCIATED CONTENT}

\section{Supporting Information}

The Supporting Information is available free of charge on the ACS Publications website.

General information, crystallographic data, computational details, NMR spectra, experimental and computed UV/vis spectra, frontier molecular orbitals, normalized excitation and emission spectra, and cyclic voltammograms (PDF)

\section{Cartesian coordinates of the optimized structures (XYZ)}

\section{Accession Codes}

CCDC 1911689-1911690 contain the crystallographic data for this paper. These data can be obtained free of charge via www.ccdc.cam.ac.uk/data_request/cif, or by e-mailing data_request@ccdc.cam.ac.uk, or by contacting The Cambridge Crystallographic Data Centre, 12 Union Road, Cambridge CB2 1EZ, UK; fax: +441223336033.

\section{AUTHOR INFORMATION}

\section{Corresponding Author}

*E-mail: maester@unizar.es.

Notes

The authors declare no competing financial interest.

\section{ACKNOWLEDGMENT}

Financial support from the MINECO of Spain (Projects CTQ201782935-P and Red de Excelencia Consolider CTQ2016-81797-REDC), Gobierno de Aragón (Group E06_17R and project LMP148_18), FEDER, and the European Social Fund is acknowledged. BIFI Institute and CESGA Supercomputing Center are acknowledged by technical support and the use of computational resources.

\section{REFERENCES}

(1) (a) You, Y.; Park, Y. Phosphorescent iridium(III) complexes: toward high phosphorescence quantum efficiency through ligand control. Dalton Trans. 2009, 1267-1282. (b) Chi, Y.; Chou, P.-T. Transition-metal phosphors with cyclometalating ligands: fundamentals and applications. Chem. Soc. Rev. 2010, 39, 638-655. (c) Chou, P.-T.; Chung, M.-W.; Lin, C.-C. Harvesting luminescence via harnessing the photophysical properties of transition metal complexes. Coord. Chem. Rev. 2011, 255, 2653-2665. (d) Yersin, H.; Rausch, A. F.; Czerwieniec, R.; Hofbeck, T.; Fischer, T. The triplet state of organo-transition metal compounds. Triplet harvesting and singlet harvesting for efficient OLEDs. Coord. Chem. Rev. 2011, 255, 2622-2652. (e) Zanoni, K. P. S.; Coppo, R. L.; Amaral, R. C.; Iha, N. Y. M. $\mathrm{Ir}(\mathrm{III})$ complexes designed for light-emitting devices: beyond the luminescence color array. Dalton Trans. 2015, 44, 14559-14573. (f) Lu, C.W.; Wang, Y.; Chi, Y. Metal Complexes with Azolate-Functionalized Multidentate Ligands: Tactical Designs and Optoelectronic Applications. Chem Eur. J. 2016, 22, 17892-17908.

(2) Li, T.-Y.; Wu, J.; Wu, Z.-G.; Zheng, Y.-X.; Zuo, J.-L; Pan, Y. Rational design of phosphorescent iridium(III) complexes for emission color tunability and their applications in OLEDs. Coord. Chem. Rev. 2018, 374, 5592.

(3) (a) Kim, T.; Lee, J.; Lee, S. U.; Lee, M. H. $o$-Carboranyl-Phosphine as a New Class of Strong-Field Ancillary Ligand in Cyclometalated Iridium(III) Complexes: Toward Blue Phosphorescence. Organometallics 2015, 34, 3455-3458. (b) Lee, Y. H.; Park, J.; Lee, J.; Lee, S. U.; Lee, M. H. Iridium Cyclometalates with Tethered $o$-Carboranes: Impact of Restricted Rotation of $o$-Carborane on Phosphorescence Efficiency. J. Am. Chem. Soc. 2015, 137, 8018-8021. (c) Nguyen, V. H.; Khoo, R. S. H.; Yip, J. H. K. $\operatorname{Ir}(2 \text {-Phenylpyridine })_{2}$ (benzene-1,2-dithiolate) Anion as a Diastereoselective Metalloligand and Nucleophile: Stereoelectronic Effect, Spectroscopy, and Computational Study of the Methylated and Aurated Complexes and Their Oxygenation Products. Inorg. Chem. 2015, 54, 2264-2277. (d) Radwan, Y. K.; Maity, A.; Teets, T. S. Manipulating the Excited States of Cyclometalated Iridium Complexes with $\beta$-Ketoiminate and $\beta$ Diketiminate Ligands. Inorg. Chem. 2015, 54, 7122-7131. (e) Kumar, S.; Hisamatsu, Y.; Tamaki, Y.; Ishitani, O.; Aoki, S. Design and Synthesis of Heteroleptic Cyclometalated Iridium(III) Complexes Containing Quinoline-Type Ligands that Exhibit Dual Phosphorescence Inorg. Chem 2016, 55, 3829-3843 (f) Yi, S.; Kim, J.-H.; Cho, Y.-J.; Lee, J.; Choi, T.-S.; Cho, D. W.; Pac, C.; Han, W.-S.; Son, H.-J.; Kang, S. O. Stable Blue Phosphorescence Iridium(III) Cyclometalated Complexes Prompted by Intramolecular Hydrogen Bond in Ancillary Ligand. Inorg. Chem. 2016, 55, 33243331. (g) Axtell, J. C.; Kirlikovali, K. O.; Djurovich, P. I.; Jung, D.; Nguyen, V. T.; Munekiyo, B.; Royappa, A. T.; Rheingold, A. L.; Spokoyny, A. M. Blue Phosphorescent Zwitterionic Iridium(III) Complexes Featuring Weakly Coordinating nido-Carborane-Based Ligands. J. Am. Chem. Soc. 2016, 138, 15758-15765. (h) Umamahesh, B.; Karthikeyan, N. S.; Sathiyanarayanan, K. I.; Malicka, J. M.; Cocchi, M. Tetrazole iridium(III) complexes as a class of phosphorescent emitters for high-efficiency OLEDs. J. Mater. Chem. C2016, 4, 10053-10060. (i) Yu, T.; Yang, F.; Chen, X.; Su, W.; Zhao, Y.; Zhang, H.; Li, J. Synthesis and characterization of greenemitting Ir(III) complexes based on a functionalized benzimidazole ligand. New J. Chem. 2017, 41, 2046-2054. (j) Jing, Y.-M.; Zhao, Y.; Zheng, Y.-X. Photoluminescence and electroluminescence of iridium(III) complexes with 2',6'-bis(trifluoromethyl)-2,4'-bipyridine and 1,3,4-oxadiazole/1,3,4thiadiazole derivative ligands. Dalton Trans. 2017, 46, 845-853. (k) Benjamin, H.; Liang, J.; Liu, Y.; Geng, Y.; Liu, X.; Zhu, D.; Batsanov, A. S.; Bryce, M. R. Color Tuning of Efficient Electroluminescence in the Blue and Green Regions Using Heteroleptic Iridium Complexes with 2Phenoxyoxazole Ancillary Ligands. Organometallics 2017, 36, 1810-1821. (1) Pal, A. K.; Henwood, A. F.; Cordes, D. B.; Slawin, A. M. Z.; Samuel, I. D. W.; Zysman-Colman, E. Blue-to-Green Emitting Neutral Ir(III) Complexes Bearing Pentafluorosulfanyl Groups: A Combined Experimental and Theoretical Study. Inorg. Chem. 2017, 56, 7533-7544. (m) Davidson, R.; Hsu, Y. T.; Bhagani, C.; Yufit, D.; Beeby, A. Exploring the Chemistry and Photophysics of Substituted Picolinates Positional Isomers in Iridium(III) Bisphenylpyridine Complexes. Organometallics 2017, 36, 2727-2735. (n) Lai, P.-N.; Brysacz, C. H.; Alam, Md. K.; Ayoub, N. A.; Gray, T. G.; Bao, J.; Teets, T. S. Highly Efficient Red-Emitting Bis-Cyclometalated Iridium Complexes. J. Am. Chem. Soc. 2018, 140, 10198-10207. (o) Congrave, D. G.; Batsanov, A. S.; Du, M.; Liu, Y.; Zhu, D.; Bryce, M. R. Intramolecular $\pi-\pi$ Interactions with a Chiral Auxiliary Ligand Control Diastereoselectivity in a Cyclometalated $\operatorname{Ir}(\mathrm{III})$ Complex. Inorg. Chem. 2018, 57, 12836-12849. (p) Na, H.; Teets, T. S. Highly Luminescent Cyclometalat- 
ed Iridium Complexes Generated by Nucleophilic Addition to Coordinated Isocyanides. J. Am. Chem. Soc. 2018, 140, 6353-6360.

(4) (a) Edkins, R. M.; Wriglesworth, A.; Fucke, K.; Bettington, S. L.; Beeby, A. The synthesis and photophysics of tris-heteroleptic cyclometalated iridium Complexes. Dalton Trans. 2011, 40, 9672-9678. (b) Baranoff, E.; Curchod, B. F. E.; Frey, J.; Scopelliti, R.; Kessler, F.; Tavernelli, I.; Rothlisberger, U.; Grätzel, M.; Nazeeruddin, Md. K. Acid-Induced Degradation of Phosphorescent Dopants for OLEDs and Its Application to the Synthesis of Tris-heteroleptic Iridium(III) Bis-cyclometalated Complexes. Inorg. Chem. 2012, 51, 215-224. (c) Xu, X.; Yang, X.; Dang, J.; Zhou, G.; Wu, Y.; Li, H.; Wong, W.-Y. Trifunctional Ir ${ }^{\mathrm{III}}$ ppy-type asymmetric phosphorescent emitters with ambipolar features for highly efficient electroluminescent devices. Chem. Commun. 2014, 50, 2473-2476. (d) Lepeltier, M.; Dumur, F.; Graff, B.; Xiao, P.; Gigmes, D.; Lalevée, J.; Mayer, C. R. Tris-cyclometalated Iridium(III) Complexes with Three Different Ligands: a New Example with 2-(2,4-Difluorophenyl)pyridine-Based Complex. Helv. Chim. Acta 2014, 97, 939-956. (e) Xu, X.; Yang, X.; Wu, Y.; Zhou, G.; Wu, C.; Wong, W.-Y. tris-Heteroleptic Cyclometalated Iridium(III) Complexes with Ambipolar or Electron Injection/Transport Features for Highly Efficient Electrophosphorescent Devices. Chem. Asian J. 2015, 10, 252-262. (f) Tamura, Y.; Hisamatsu, Y.; Kumar, S.; Itoh, Y.; Sato, K.; Kuroda, R.; Aoki, S. Efficient Synthesis of Tris-Heteroleptic Iridium(III) Complexes Based on the $\mathrm{Zn}^{2+}$-Promoted Degradation of TrisCyclometalated Iridium(III) Complexes and Their Photophysical Properties. Inorg. Chem. 2017, 56, 812-833. (g) Hisamatsu, Y.; Kumar, S.; Aoki, S. Design and Synthesis of Tris-Heteroleptic Cyclometalated Iridium(III) Complexes Consisting of Three Different Nonsymmetric Ligands Based on Ligand-Selective Electrophilic Reactions via Interligand HOMO Hopping Phenomena. Inorg. Chem. 2017, 56, 886-899. (h) Cudré, Y.; Franco de Carvalho, F.; Burgess, G. R.; Male, L.; Pope, S. J. A.; Tavernelli, I.; Baranoff, E. Tris-heteroleptic Iridium Complexes Based on Cyclometalated Ligands with Different Cores. Inorg. Chem. 2017, 56, 11565-11576. (i) Tamura, Y.; Hisamatsu, Y.; Kazama, A.; Yoza, K.; Sato, K.; Kuroda, R.; Aoki. S. Stereospecific Synthesis of Tris-heteroleptic Tris-cyclometalated Iridium(III) Complexes via Different Heteroleptic Halogen-Bridged Iridium(III) Dimers and Their Photophysical Properties. Inorg. Chem. 2018, 57, 45714589. (j) Feng, Z.; Wang, D.; Yang, X.; Jin, D.; Zhong, D.; Liu, B.; Zhou,G.; Ma, M.; Wu, Z. Asymmetric Heteroleptic Ir(III) Phosphorescent Complexes with Aromatic Selenide and Selenophene Groups: Synthesis and Photophysical, Electrochemical, and Electrophosphorescent Behaviors. Inorg. Chem. 2018, 57, 11027-11043.

(5) (a) Williams, J. A. G.; Wilkinson, A. J.; Whittle, V. L. Light-emitting iridium complexes with tridentate ligands. Dalton Trans. 2008, 2081-2099. (b) Williams, J. A.G. The coordination chemistry of dipyridylbenzene: Ndeficient terpyridine or panacea for brightly luminescent metal complexes? Chem. Soc. Rev. 2009, 38, 1783-1801.

(6) (a) Sauvage, J.-P.; Collin, J.-P.; Chambron, J.-C.; Guillerez, S.; Coudret, C.; Balzani, V.; Barigelletti, F. de Cola, L.; Flamigni, L. Ruthenium(II) and Osmium(II) Bis(terpyridine) Complexes in Covalently-Linked Multicomponent Systems: Synthesis, Electrochemical Behavior, Absorption Spectra, and Photochemical and Photophysical Properties. Chem. Rev. 1994, 94, 993-1019. (b) Abrahamsson, M.; Jäger, M.; Kumar, R. J.; Österman, T.; Persson, P.;| Becker, H.-C; Johansson, O.; Hammarström, L. Bistridentate Ruthenium(II)polypyridyl-Type Complexes with Microsecond ${ }^{3}$ MLCT State Lifetimes: Sensitizers for Rod-Like Molecular Arrays. J. Am. Chem. Soc. 2008, 130, 15533-15542.

(7) Chi, Y.; Chang, T.-K.; Ganesan, P.; Rajakannu, P. Emissive bistridentate $\mathrm{Ir}(\mathrm{III})$ metal complexes: Tactics, photophysics and applications. Coord. Chem. Rev. 2017, 346, 91-100.

(8) Wilkinson, A. J.; Goeta, A. E.; Foster, C. E.; Williams, J. A. G. Synthesis and Luminescence of a Charge-Neutral, Cyclometalated Iridium(III) Complex Containing $\mathrm{N}^{\wedge} \mathrm{C}^{\wedge} \mathrm{N}$ - and $\mathrm{C}^{\wedge} \mathrm{N}^{\wedge} \mathrm{C}$-Coordinating Terdentate Ligands. Inorg. Chem. 2004, 43, 6513-6515.

(9) (a) Wilkinson, A. J.; Puschmann, H.;Howard, J. A. K.; Foster, C. E.; Williams, J. A. G. Luminescent Complexes of Iridium(III) Containing $\mathrm{N}^{\wedge} \mathrm{C}^{\wedge} \mathrm{N}$-Coordinating Terdentate Ligands. Inorg. Chem. 2006, 45, 86858699. (b) Esteruelas, M. A.; Gómez-Bautista, D.; López, A. M.; Oñate, E.; Tsai, J.-Y.; Xia, C. $\eta^{1}$-Arene Complexes as Intermediates in the Preparation of Molecular Phosphorescent Iridium(III) Complexes. Chem. Eur. J. 2017, 23, 15729-15737.

(10) Tong, B.; Ku, H.-Y.; Chen, I.-J.; Chi, Y.; Kao, H.-C.; Yeh, C.-C.; Chang, C.-H.; Liu, S.-H.; Lee, G.-H.; Chou, P.-T. Heteroleptic Ir(III) phosphors with bis-tridentate chelating architecture for high efficiency OLEDs. J. Mater. Chem. C, 2015, 3, 3460-3471.

(11) (a) Sajoto, T.; Djurovich, P. I.; Tamayo, A.; Yousufuddin, M.; Bau, R.; Thompson, M. E. Holmes, R. J.; Forrest, S. R. Blue and Near-UV Phosphorescence from Iridium Complexes with Cyclometalated Pyrazolyl or NHeterocyclic Carbene Ligands. Inorg. Chem. 2005, 44, 7992-8003. (b) Chang, C.-F.; Cheng, Y.-M.; Chi, Y.; Chiu, Y.-C.; Lin, C.-C.; Lee, G.-H.; Chou, P.-T.; Chen, C.-C.; Chang, C.-H.; Wu, C.-C. Highly Efficient BlueEmitting Iridium(III) Carbene Complexes and Phosphorescent OLEDs. Angew. Chem. Int. Ed. 2008, 47, 4542-4545. (c) Chien, C.-H.; Fujita, S.; Yamoto, S.; Hara, T.; Yamagata, T.; Watanabe M.; Mashima K. Stepwise and one-pot syntheses of Ir(III) complexes with imidazolium-based carbene ligands. Dalton Trans. 2008, 916-923. (d) Tsurugi, H.; Fujita, S.; Choi, G.; Yamagata, T.; Ito, S.; Miyasaka, H.; Mashima, K. Carboxylate Ligand-Induced Intramolecular C-H Bond Activation of Iridium Complexes with N-Phenylperimidine-Based Carbene Ligands. Organometallics, 2010, 29, 4120-4129. (e) Hsieh, C.-H.; Wu, F.-I.; Fan, C.-H.; Huang, M.J.; Lu, K.-Y.; Chou, P.-Y.; Yang, Y.-H. O.; Wu, S.-H.; Chen, I-C.; Chou, S.H.; Wong, K.-T.; Cheng, C.-H. Design and Synthesis of Iridium Bis(carbene) Complexes for Efficient Blue Electrophosphorescence. Chem. Eur. J. 2011, 17, 9180-9187. (f) Lu, K.-Y.; Chou, H.-H.; Hsieh, C.H.; Yang, Y.-H. O.; Tsai, H.-R.; Tsai, H.-Y.; Hsu, L.-C.; Chen, C.-Y.; Chen, I-C.; Cheng, C.-H. Wide-Range Color Tuning of Iridium Biscarbene Complexes from Blue to Red by Different $\mathrm{N}^{\wedge} \mathrm{N}$ Ligands: an Alternative Route for Adjusting the Emission Colors. Adv. Mater. 2011, 23, 49334937. (g) Zhou, Y.; Jia, J.; Li, W.; Fei, H.; Zhou, M. Luminescent biscarbene iridium(III) complexes as living cell imaging reagents. Chem. Com mun., 2013, 49, 3230-3232. (h) Li, H.; Yin, Y.-M.; Cao, H.-T.; Sun, H.-Z.; Wang, L.; Shan, G.-G.; Zhu, D.-X.; Su, Z.-M.; Xie, W.-F. Efficient greenishblue phosphorescent iridium(III) complexes containing carbene and triazole chromophores for organic light-emitting diodes. J. Organomet Chem. 2014, 753, 55-62. (i) Shang, X.; Han, D.; Zhan, Q.; Zhang, G.; Li, D. DFT and TD-DFT Study on the Electronic Structures and Phosphorescent Properties of a Series of Heteroleptic Iridium(III) Complexes. Organometallics, 2014, 33, 3300-3308. (j) Stringer, B. D.; Quan, L. M.; Barnard, P. J.; Wilson, D. J. D.; Hogan, C. F. Iridium Complexes of N-Heterocyclic Carbene Ligands: Investigation into the Energetic Requirements for Efficient Electrogenerated Chemiluminescence. Organometallics 2014, 33 , 4860-4872. (k) Li, T.-Y.; Liang, X.; Zhou, L.; Wu, C.; Zhang, S.; Liu, X.; Lu, G.-Z.; Xue, L.-S.; Zheng, Y.-X.; Zuo, J.-L. N-Heterocyclic Carbenes: Versatile Second Cyclometalated Ligands for Neutral Iridium(III) Heteroleptic Complexes. Inorg. Chem. 2015, 54, 161-173. (1) Leopold, H.; Císarová, I.; Strassner, T. Phosphorescent $\mathrm{C}^{\wedge} \mathrm{C}^{*}$ Cyclometalated Thiazol-2ylidene Iridium(III) Complexes: Synthesis, Structure, and Photophysics. Organometallics 2017, 36, 3016-3018.

(12) (a) Bolaño, T.; Esteruelas, M.A.; Fernández, I.; Oñate, E.; Palacios, A.; Tsai, J.-Y.; Xia, C. Osmium(II)-Bis(dihydrogen) Complexes Containing $\mathrm{C}_{\text {aryl }}, \mathrm{C}_{\mathrm{NHC}}-$ Chelate Ligands: Preparation, Bonding Situation, and Acidity. Organometallics 2015, 34, 778-789. (b) Huynh, H. V. Electronic Properties of N-Heterocyclic Carbenes and Their Experimental Determination. Chem. Rev. 2018, 118, 9457-9492.

(13) Jacquemin, D.; Escudero, D. The short device lifetimes of blue PhOLEDs: insights into the photostability of blue Ir(III) complexes Chem. Sci., 2017, 8, 7844-7850.

(14) See for example: (a) Poyatos, M.; Mata, J. A.; Peris, E. Complexes with Poly(N-heterocyclic carbene) Ligands: Structural Features and Catalytic Applications. Chem. Rev. 2009, 109, 3677-3707. (b) Raynal, M.; Pattacini, R.; Cazin, C. S. J.; Vallée, C.; Olivier-Bourbigou, H.; Braunstein, $\mathrm{P}$. Reaction Intermediates in the Synthesis of New Hydrido, NHeterocyclic Dicarbene Iridium(III) Pincer Complexes. Organometallics 2009, 28, 4028-4047. (c) Chianese, A. R.; Mo, A.; Lampland, N. L.; Swartz, R. L.; Bremer, P. T. Iridium Complexes of CCC-Pincer NHeterocyclic Carbene Ligands: Synthesis and Catalytic C-H Functionalization. Organometallics 2010, 29, 3019-3026. (d) Zuo, W.; Braunstein, P. 
Stepwise synthesis of a hydrido, $N$-heterocyclic dicarbene iridium(III) pincercomplex featuring mixed NHC/abnormal NHC ligands. Dalton Trans. 2012, 41, 636-643. (e) Zuo, W.; Braunstein, P. N-Heterocyclic Dicarbene Iridium(III) Pincer Complexes Featuring Mixed NHC/Abnormal NHC Ligands and Their Applications in the Transfer Dehydrogenation of Cyclooctane. Organometallics 2012, 31, 2606-2615. (f) Chianese, A. R.; Shaner, S. E.; Tendler, J. A.; Pudalov, D. M.; Shopov, D. Y.; Kim, D.; Rogers, S. L.; Mo, A. Iridium Complexes of Bulky CCCPincer N-Heterocyclic Carbene Ligands: Steric Control of Coordination Number and Catalytic Alkene Isomerization. Organometallics 2012, 31, 7359-7367. (g) Darmawan, N.; Yang, C.-H.; Mauro, M.; Raynal, M.; Heun, S. Pan, Buchholz, J. H.; Braunstein, P.; De Cola, L. Efficient NearUV Emitters Based on Cationic Bis-Pincer Iridium(III) Carbene Complexes. Inorg. Chem. 2013, 52, 10756-10765. (h) Jagenbrein, M.; Danopoulos, A. A.; Braunstein, P. Bis-N-heterocyclic carbene 'pincer' ligands and iridium complexes with $\mathrm{CF}_{3}$ - Substituted phenylene backbone. J. Organomet. Chem. 2015, 775, 169-172. (i) Esteruelas, M. A.; López, A. M.; Oñate, E.; San-Torcuato, A.; Tsai, J.-Y.; Xia, C. Formation of Dinuclear Iridium Complexes by NHC-Supported $\mathrm{C}-\mathrm{H}$ Bond Activation. Organometallics 2017, 36, 699-707.

(15) Raynal, M.; Cazin, C. S. J.; Vallée, C.; Olivier-Bourbigou, H.; Braunstein, P. An unprecedented, figure-of-eight, dinuclear iridium(I) dicarbene and new iridium(III) 'pincer' complexes. Chem. Commun. 2008, 3983-3985.

(16) Bauer, E. B.; Andavan, G. T. S.; Hollis, T. K.; Rubio, R. J.; Cho, J.; Kuchenbeiser, G. R.; Helgert, T. R.; Letko, C. S.; Tham, F. S. Air- and Water-Stable Catalysts for Hydroamination/Cyclization. Synthesis and Application of CCC-NHC Pincer Complexes of Rh and Ir. Org. Lett. 2008, 6, 1175-1178.

(17) (a) Kuei, C.-Y.; Tsai, W.-L.; Tong, B.; Jiao, M.; Lee, W.-K.; Chi, Y.; Wu, C.-C.; Liu, S.-H.; Lee, G.-H.; Chou, P.-T. Bis-Tridentate Ir(III) Complexes with Nearly Unitary RGB Phosphorescence and Organic LightEmitting Diodes with External Quantum Efficiency Exceeding 31\%. Adv. Mater. 2016, 28, 2795-2800. (b) Kuei, C.-Y.; Liu, S.-H.; Chou, P.-T. Lee, G.-H.; Chi, Y. Room temperature blue phosphorescence: a combined experimental and theoretical study on the bis-tridentate $\operatorname{Ir}(\mathrm{III})$ metal complexes. Dalton Trans. 2016, 45, 15364-15373. (c) Kuo, H.-H.; Chen, Y.-T.; Devereux, L. R.; Wu, C.-C.; Fox, M. A.; Kuei, C.-Y.; Chi, Y.; Lee G.H. Bis-Tridentate Ir(III) Metal Phosphors for Efficient Deep-Blue Organic Light-Emitting Diodes. Adv. Mater. 2017, 29, 1702464. (d) Kuo, H.-H.; Zhu, Z.-L.; Lee, C.-S.; Chen, Y.-K.; Liu, S.-H.; Chou, P.-T.; Jen, A. K.-Y.; Chi, Y. Bis-Tridentate Iridium(III) Phosphors with Very High Photostability and Fabrication of Blue-Emitting OLEDs. Adv. Sci. 2018, 1800846.

(18) (a) Chen, J.-L.; Wu, Y.-H.; He, L.-H.; Wen, H.-R.; Liao, J.; Hong, R. Iridium(III) Bis-tridentate Complexes with 6-(5Trifluoromethylpyrazol-3-yl)-2,2'-bipyridine Chelating Ligands: Synthesis, Characterization, Photophysical Properties. Organometallics 2010, 29, 2882-2891. (b) Lin, J.; Chau, N.-Y.; Liao, J.-L.; Wong, W.-Y.; Lu, C.-Y.; Sie, Z.-T.; Chang, C.-H.; Fox, M. A.; Low, P. J.; Lee, G.-H.; Chi, Y. BisTridentate Iridium(III) Phosphors Bearing Functional 2-Phenyl-6(imidazol-2-ylidene)pyridine and 2-(Pyrazol-3-yl)-6-phenylpyridine Chelates for Efficient OLEDs. Organometallics 2016, 35, 1813-1824. (c) Lin, J.; Wang, Y.; Gnanasekaran, P.; Chiang, Y.-C.; Yang, C.-C.; Chang, C.H.; Liu, S.-H.; Lee, G.-H.; Chou, P.-T.; Chi, Y.; Liu, S.-W. Unprecedented Homoleptic Bis-Tridentate Iridium(III) Phosphors: Facile, Scaled-Up Production, and Superior Chemical Stability. Adv. Funct. Mater. 2017, 27, 1702856.

(19) Esteruelas, M. A.; López, A. M.; Oñate, E.; San-Torcuato, A.; Tsai, J.-Y.; Xia, C. Preparation of Phosphorescent Iridium(III) Complexes with a Dianionic C,C,C,C-Tetradentate Ligand. Inorg. Chem. 2018, 57, 3720-3730.

(20) See for exemple: (a) Hahn, F. E.; Holtgrewe, C., Pape, T.; Martin, M.; Sola, E.; Oro, L. A. Iridium Complexes with N-Allyl-Substituted Benzimidazol-2-ylidene Ligands and Their Application in Catalytic Transfer Hydrogenation. Organometallics 2005, 24, 2203-2209. (b) Jiménez, M. V.; Fernández-Tornos, J.; Pérez-Torrente, J. J.; Modrego, F. J.; Winterle, S.; Cunchillos, C.; Lahoz, F. J.; Oro. L. A. Iridium(I) Complexes with Hemila- bile N-Heterocyclic Carbenes: Efficient and Versatile Transfer Hydrogenation Catalysts. Organometallics 2011, 30, 5493-5508. (c) Peñafiel, I.; Pastor, I. M.; Yus, M.; Esteruelas, M. A.; Oliván, M. Preparation, Hydrogen Bonds, and Catalytic Activity in Metal-Promoted Addition of Arylboronic Acids to Enones of a Rhodium Complex Containing an NHC Ligand with an Alcohol Function. Organometallics 2012, 31, 6154-6161. (d) Blanco, M.; Álvarez, P.; Blanco, C.; Jiménez, M. V.; Fernández-Tornos, J.; PérezTorrente, J. J.; Oro. L. A.; Menéndez, R. Enhanced Hydrogen-Transfer Catalytic Activity of Iridium N-Heterocyclic Carbenes by Covalent Attachment on Carbon Nanotubes. ACS Catal. 2013, 3, 1307-1317.

(21) Oxidations at -0.16 and $0.61 \mathrm{~V}$ for 4 and -0.15 and $0.64 \mathrm{~V}$ for 5 and a reduction at -1.24 for 4 and $-1.31 \mathrm{~V}$ for 5 , probably due to the ligands, are also observed.

(22) Zanoni, K. P. S.; Kariyazaki, B. K., Ito, A.; Brennaman, M. K.; Meyer, T. J.; Murakami Iha, N. Y. Blue-Green Iridium(III) Emitter and Comprehensive Photophysical Elucidation of Heteroleptic Cyclometalated Iridium(III) Complexes. Inorg. Chem. 2014 53, 4089-4099.

(23) Sajoto, T.; Djurovich, P. I.; Tamayo, A. B.; Oxgaard, J.; Goddard III, W. A.; Thompson, M. E. Temperature Dependence of Blue Phosphorescent Cyclometalated Ir(III) Complexes. J. Am. Chem. Soc. 2009, 131, 9813-9822.

(24) Usón, R.; Oro, L. A. Cabeza, J. Dinuclear methoxy, cyclooctadiene, and barrelene complexes of rhodium(I) and iridium(I). In Inorganic Syntheses; Kirschner, S., Ed.; Wiley, 2007; Vol. 23, pp 126-130.

(25) Ho, Y.-M.; Koo, C.-K.; Wong, K.-L.; Kong, H.-K.; Chan, C. T.-L.; Kwok, W.-M.; Chow, C.-F.; Lam, M. H.-W.; Wong, W.-Y. The synthesis and photophysical studies of cyclometalated $\mathrm{Pt}(\mathrm{II})$ complexes with $C, N, N$ ligands containing imidazolyl donors Dalton Trans. 2012, 41, 1792-1800.

(26) Fu, L.; Pan, M.; Li, Y.-H.; Wu, H.-B.; Wang, H.-P.; Yan, C.; Li, K.; Wei, S.-C.; Wang, Z.; Su, C.-Y. A butterfly-like yellow luminescent Ir(III) complex and its application in highly efficient polymer light-emitting devices. J. Mater. Chem. 2012, 22, 22496-22500. 
For Table of Contents Only

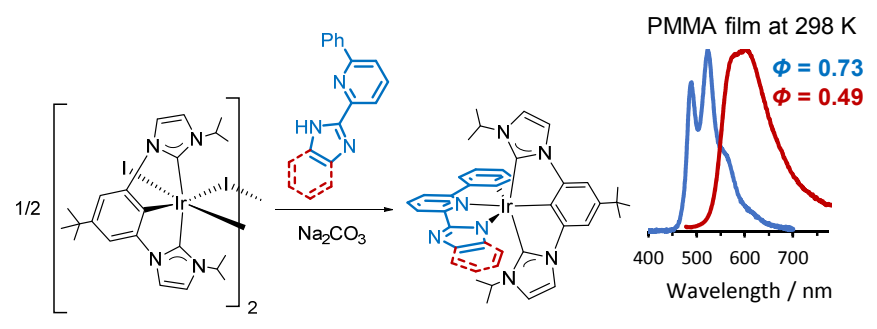

